\title{
In planta high levels of hydrolysable tannins inhibit peroxidase mediated anthocyanin degradation and maintain abaxially red leaves of Excoecaria Cochinchinensis
}

Honghui Luo ${ }^{1+}$, Wenjun $\mathrm{Li}^{1,2+}$, Xin Zhang ${ }^{1,2+}$, Shuangfan Deng ${ }^{2}$, Qiuchan $\mathrm{Xu}^{2}$, Ting Hou ${ }^{2}$, Xuequn Pang ${ }^{1,2}$, Zhaoqi Zhang ${ }^{1 *}$ and Xuelian Zhang ${ }^{1,2^{*}}$ (D)

\begin{abstract}
Background: Abaxially anthocyanic leaves of deeply-shaded understorey plants play important ecological significance for the environmental adaption. In contrast to the transient pigmentation in other plants, anthocyanins are permanently presented in these abaxially red leaves, however, the mechanism for the pigment maintenance remains unclear. In the present study, we investigated phenolic metabolites that may affect pigment stability and degradation in Excoecaria cochinchinensis (a bush of permanently abaxial-red leaves), via a comparison with Osmanthus fragrans (a bush of transiently red leaves).

Results: High levels of galloylated anthocyanins were identified in the Excoecaria but not in the Osmanthus plants. The galloylated anthocyanin showed slightly higher stability than two non-galloylated anthocyanins, while all the 3 pigments were rapidly degraded by peroxidase (POD) in vitro. High levels of hydrolysable tannins [mainly galloylglucoses/ellagitannins (GGs/ETs)] were identified in Excoecaria but none in Osmanthus. GGs/ETs showed inhibition effect on POD, with IC50 ranged from 35.55 to $83.27 \mu \mathrm{M}$, correlated to the markedly lower POD activities detected in Excoecaria than in Osmanthus. Strong copigmentation was observed for GGs/ETs and anthocyanins, with more than $30 \%$ increase in the red intensity of non-galloylated anthocyanin solutions. In the leaf tissue, the hydrolysable tannins were observed to be co-localized with anthocyanins at the abaxial layer of the Excoecaria leaves, correlated to the low POD activity, more acidity and increased red intensity of the tissue.

Conclusion: The results suggest that the Excoecaria leaves accumulate a distinct group of phenolic metabolites, mainly GGs/ETs, at the abaxial layer, which prevent anthocyanin degradation and increase the pigment stability, and consequently lead to the permanent maintenance of the red leaves.
\end{abstract}

Keywords: Galloylglucoses/Ellagitannins, Anthocyanin maintenance, Peroxidase, Abaxially red leaves, Excoecaria cochinchinensis

\footnotetext{
* Correspondence: zqzhang@scau.edu.cn; xuelianzhang@scau.edu.cn

${ }^{\dagger}$ Honghui Luo, Wenjun Li and Xin Zhang contributed equally to this work.

${ }^{1}$ State Key Laboratory for Conservation and Utilization of Subtropical

Agro-bioresources/ Guangdong Provincial Key Laboratory of Postharvest

Science of Fruits and Vegetables/ College of Horticulture, South China

Agricultural University, Guangzhou 510642, China

Full list of author information is available at the end of the article
}

(c) The Author(s). 2019 Open Access This article is distributed under the terms of the Creative Commons Attribution 4.0 International License (http://creativecommons.org/licenses/by/4.0/), which permits unrestricted use, distribution, and reproduction in any medium, provided you give appropriate credit to the original author(s) and the source, provide a link to the Creative Commons license, and indicate if changes were made. The Creative Commons Public Domain Dedication waiver (http://creativecommons.org/publicdomain/zero/1.0/) applies to the data made available in this article, unless otherwise stated. 


\section{Background}

Anthocyanins are the major pigments in plant kingdom, acting as protectors of photosynthetic tissues against damaging light, as signals for flowers and fruits to attract pollinators and seed dispersers [1-4]. In general, the pigments are transiently accumulated and degraded after their roles have been accomplished [5, 6], however, permanent presence of the pigments in the abaxially red leaves are found for many understorey plants. In contrast to intensive studies of ecological significance of the abaxial anthocyanins in the deeply-shaded plants, the mechanism for the pigment maintenance has rarely been dissected.

Anthocyanins accumulation usually occurs in the juvenile leaves of many plants, where the photosynthetic apparatus is not fully functional, and light in excess of photosynthetic capacity can lead to cellular damage $[7,8]$. Predominantly located in the upper and/or lower epidermis of leaves, anthocyanins act as an efficient sunscreen to protect photosynthetic mesophyll cells [9]. Accordingly, under nature light, less photoinhibition of leaves, as represented by lower non-photochemical quenching (NPQ) and total xanthophyll to chlorophyll (VAZ/Chl) values, was found for many anthocyanic (red) species than anthocyanin-less ones [10-14]. In addition, anthocyanin biosynthesis in plant leaves is upregulated in response to various stresses, such as high UV radiation, low temperature [15], which is part of a mechanism to mitigate the effects of stress and enhance plant tolerance [16]. As the leaves mature and develop protective waxes, or are transferred to shade or the environmental stresses disappear, anthocyanins decrease rapidly, and the leaves turn completely green $[1,6,17]$. The decrease of anthocyanins presumably corresponds to a decreased need for photoprotection, to allow leaves to utilize higher light intensities $[1,18,19]$.

Alternatively, anthocyanin presence in leaves may be permanent [20], and anthocyanins in these leaves are most commonly abaxial [20,21]. The plants of permanently pigmented leaves are usually originated from the forest understoreys, have different color patterns on the surface, known as leaf variegation and can be popular as ornamental plants, for example, Cyclamen purpurascens [22], Begonia fimbristipula [23] and Excoecaria cochinchinensis Lour. Abaxial anthocyanins in these plants were proposed to weaken the green light to protect photosynthetic mesophyll cells during intermittent exposure to high-intensity sunlight (i.e. sun-patches) [23-25]. This photoprotective function of the abaxial anthocyanins is supported by the higher chlorophyll content and lower $\mathrm{Chl} \mathrm{a} / \mathrm{b}$ ratios in the anthocyanic (red) versus acyanic (non-red) leaves of Begonia heracleifolia (Cham. and Schltdl.) [24]. In contrast to the intensive studies of the ecological relevance of abaxially red leaves, the mechanism that anthocyanins are maintained and avoided from shade-promoted anthocyanin degradation, has been interested by researchers for many years, but has not yet been clarified [26, 27].

The concentration of anthocyanins in plant tissues is determined by the biosynthesis, degradation and stability of pigments in plants. In contrast to the deep knowledge on their biosynthesis $[28,29]$, anthocyanins degradation and stability in plant tissues are still not well known [6, 30, 31]. Enzymatic degradation has been considered to be responsible for anthocyanin breakdown in planta [6,30], leading to pigment concentration reduction and red color fading. Polyphenol oxidases (PPOs) were presumed to be of anthocyanin degradation activities based on their abilities to degrade the pigments in fruit or fruit juice [32-34]. In plants, PPOs are located in cytosol and plastids [32], implying that PPOs might not be the enzymes that degrade the vacuole-located anthocyanins in vivo. In our previous study, an anthocyanin degradation enzyme (ADE) was purified from Litchi pericarp and identified as a laccase (ADE/LAC). The enzyme was demonstrated to be located in vacuoles and degraded anthocyanins coupled with epicatechin oxidation [35]. Recently, a basic peroxidase, BcPrx01, was found to be responsible for the in vivo degradation of anthocyanins in Brunfelsia calycina. BcPrx01 has the ability to degrade complex anthocyanins. It co-localizes with these pigments in the vacuoles of petals, and both mRNA and protein levels of BcPrx01 are greatly induced parallel to the degradation of anthocyanins [36]. Some environmental factors, such as high temperature and low density light, have been reported to enhance the degradation of anthocyanins by activating anthocyanin degradation peroxidase activity $[15,31]$.

Anthocyanin maintenance in leaves may also be influenced by anthocyanin stabilities, which were affected by their molecular structures $[37,38]$, the intravacuolar $\mathrm{pH}$ conditions, and the co-pigmentation [6,39]. At $\mathrm{pH}<3.0$, not only the red color of anthocyanins was intensified, but also the stability of the pigments increased [40]. On the contrary, increased $\mathrm{pH}$ in the vacuole of senescing tissue may decrease the stability of the anthocyanins and cause degradation [41, 42]. It was found that the interaction between anthocyanin and coexisting colorless flavonoid components in the vacuoles prevented hydration of the anthocyanidin nucleus and brought about the color stabilization [28, 43]. This interaction, also called co-pigmentation, was able to increase the pigment color intensity and stability $[44,45]$.

In this paper, to investigate the mechanism of abaxial anthocyanin maintenance, we chose Excoecaria cochinchinensis as material. Excoecaria distributes throughout tropical Asia [46], growing wild and also being cultivated as a medicinal and garden bush, and characterized by the features that its leaves are nearly opposite, deep green above, 
and purple red beneath [47]. We chose another garden bush, Osmanthus fragrans var. semperflorens, with rapid anthocyanin degradation during leaf maturation [48], as a reference plant to investigate the mechanism of anthocyanin maintenance in Excoecaria. Anthocyanin components, activities of anthocyanin degradation-related enzymes $(\mathrm{ADE})$, and the factors affecting the stability of the pigments in the two plants were analyzed in the present study. High levels of hydrolysable tannins [mainly galloylglucoses/ellagitannins (GGs/ETs)] were found to be colocalized with the anthocyanins in the leaves of Excoecaria. The substances inhibited peroxidases-mediated anthocyanin degradation and increased the pigments color density, which may be one of major factors for permanent maintenance of abaxially red leaves.

\section{Result}

\section{Excoecaria leaves maintain abaxially red during leaf} maturation

The young leaves of Excoecaria and Osmanthus unfurled in red at both adaxial and abaxial surfaces. Completely greening occurred at the adaxial surface of the
Excoecaria leaves, while the abaxial surface of the leaves maintained red in the process of leaf maturation (Fig. 1A). Osmanthus leaves gradually lost the red color and completely turned green at both sides (Fig. 1B). In the present study, stage 1, 2 and 3 were used to indicate the leaves at the stages of red, greening and completely adaxially green for both species (Fig. 1A and B). Microscopic observation of the cross sections of the leaves showed that large amounts of anthocyanins mainly located at the abaxial surface of Excoecaria leaves at the 3 stages (Fig. 1C). In contrast, anthocyanins located at both the adaxial/abaxial surface of leaves at stage 1 and 2 of Osmanthus, no anthocyanins were observed at stage 3 (Fig. 1D). To investigate whether color pattern of the leaves of the two species is related to the change in anthocyanins, the pigment contents during leaf maturation was determined. Around $110 \mathrm{~A}_{530 \mathrm{~nm}} / \mathrm{g} \mathrm{FW}$ anthocyanins were detected in both plants at stage 1 . In contrast to around 90\% reduction in anthocyanin content recorded in Osmanthus leaves from stage 1 to 3 , no reduction in anthocyanin content was detected in Excoecaria leaves (Fig. 1E). With the leaf greening, chlorophyll contents

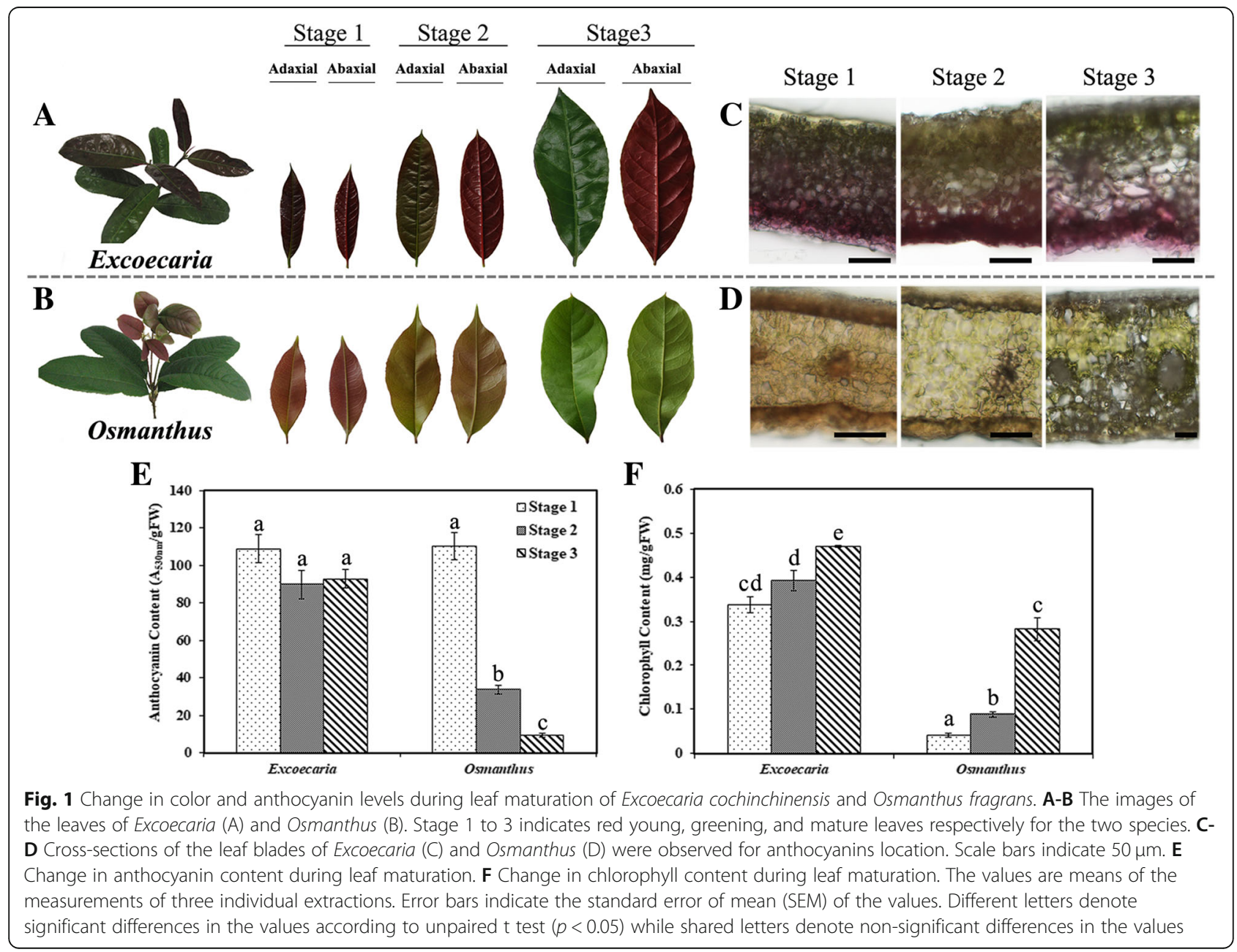


increased from 0.34 to 0.47 and 0.05 to $0.3 \mathrm{mg} / \mathrm{g} \mathrm{FW}$ respectively in Excoecaria and Osmanthus (Fig. 1F). These results indicated that, during leaf maturation, anthocyanins were maintained in Excoecaria, not like the large anthocyanin degradation in Osmanthus leaves.

High levels of galloylated anthocyanins were identified in Excoecaria but not in Osmanthus leaves

To identify the anthocyanin molecules in Excoecaria and Osmanthus leaves, the anthocyanins in Excoecaria and Osmanthus leaves at stage 1 were purified by a Sephadex LH-20 column chromatography respectively. In the elution profiles, one major A510 nm peak was observed for each species, and the red fractions including No.104127 tubes for Excoecaria sample and No.44-54 tubes for Osmanthus sample were analyzed by UPLC-DADQTOF-MS/MS respectively (Fig. 2A and B). UPLC-DAD analysis revealed six and five distinct anthocyanins in
Excoecaria and Osmanthus respectively (Fig. 2C and D). According to comparison of the $\mathrm{m} / \mathrm{z}$ and MS/MS fragment profiles of each anthocyanin positive ion with the information in "METLIN" database, six anthocyanins (No. 1-6) in Excoecaria were identified (Table 1), including cyanidin 3-O-glucoside, delphinidin 3-(2"-galloylgalactoside), cyanidin 3-(2"-galloylglucoside), cyanidin 3-Orutinoside, petunidin 3-sophoroside and peonidin 3gentiobioside (Table 1, Fig. 2E). Five identified anthocyanins (No.7-11) in Osmanthus were cyanidin 3-Orutinoside, delphinidin 3-neohesperidoside, cyanidin 3-[6(6- $\rho$-coumarylglucosyl)-2-xylosylgalactoside, pelargonidin 3-rhamnoside-5-glucoside and cyanidin 5-O-glucoside (Table 1, Fig. 2F). Based on the UPLC-DAD profiles represented by absorbance at $280 \mathrm{~nm}$, cyanidin 3-(2"-galloylglucoside) (No. 3) and cyanidin 3-O-glucoside (No. 1) were regarded as the major anthocyanins in Excoecaria (Fig. 2C), while cyanidin 3-O-rutinoside (No. 7) was the
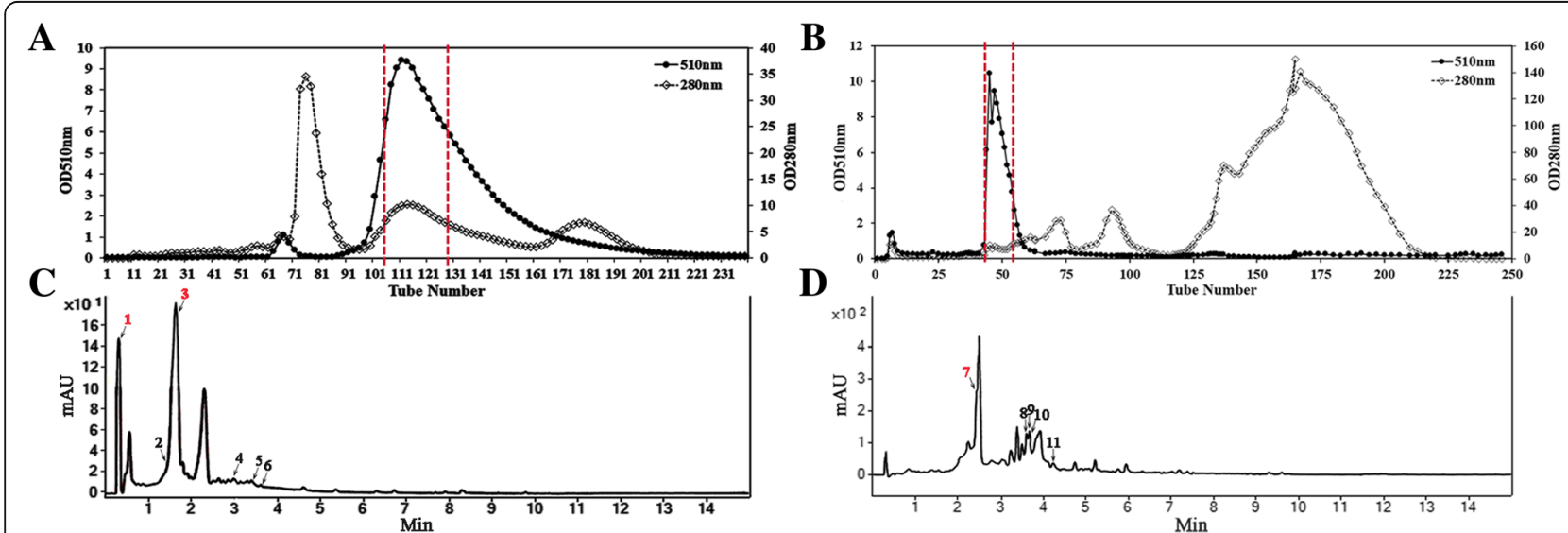

$\mathbf{E}$
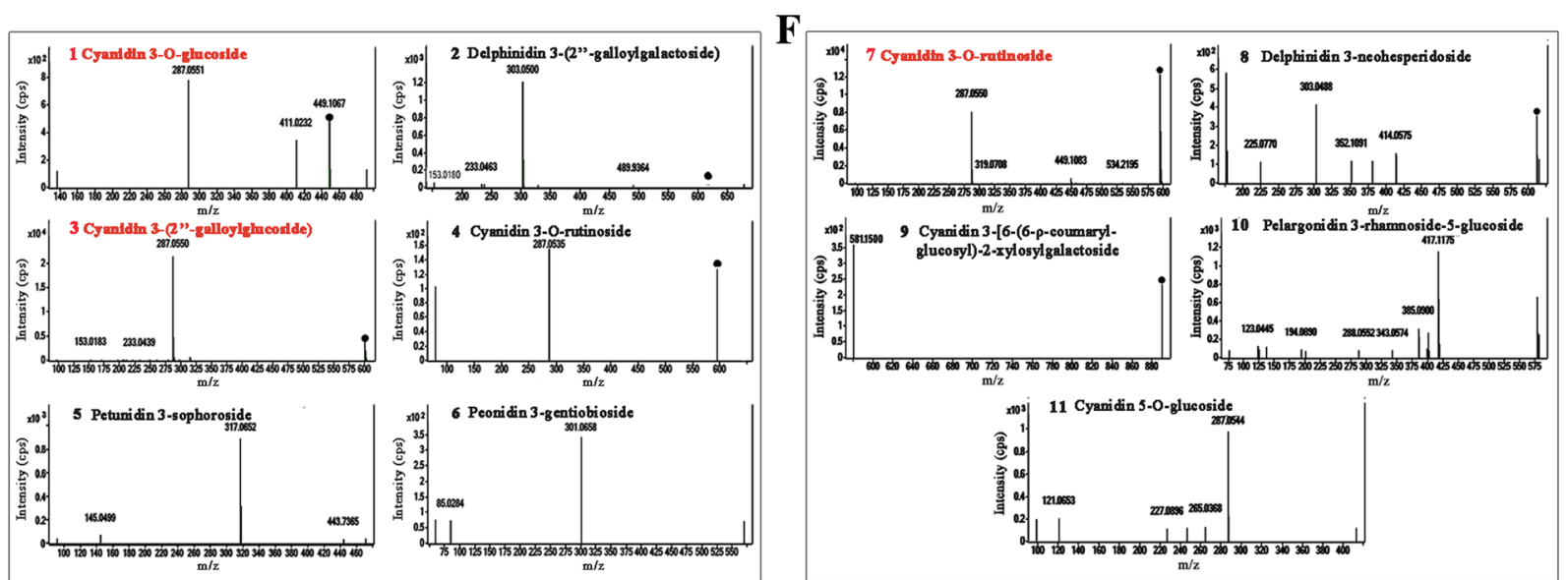

Fig. 2 Identification of the main anthocyanins in the leaves of Excoecaria and Osmanthus, using UPLC-DAD-QTOF-MS/MS. A-B Anthocyanin purification profiles by column chromatography. Absorbance at $510 \mathrm{~nm}$ and $280 \mathrm{~nm}$ was determined in the fractions of Sephadex LH-20 column chromatography for the anthocyanin purification of Excoecaria (A) and Osmanthus (B) respectively. The major anthocyanin fractions as the indicated peaks between two dotted lines were collected for UPLC-DAD-QTOF-MS/MS analysis. C-D Anthocyanin UPLC-DAD profiles represented by absorbance at $280 \mathrm{~nm}$. The anthocyanin fraction from Excoecaria (C) and Osmanthus (D) leaves as indicated in (A) and (B) were respectively analyzed by UPLC-DAD-QTOF-MS/MS. E-F MS/MS spectra of the main anthocyanins detected in Excoecaria (E) and Osmanthus (F) respectively. The prediction of the anthocyanins in (E-F) were based on the comprehensive MS/MS metabolite database "METLIN" (https://metlin.scripps.edu/) 
Table 1 The main anthocyanins detected in the leaves using UPLC-DAD-QTOF-MS/MS

\begin{tabular}{|c|c|c|c|c|c|c|}
\hline \multirow[t]{2}{*}{ Species } & \multirow{2}{*}{$\begin{array}{l}\text { Compound } \\
\text { No. }^{a}\end{array}$} & \multirow{2}{*}{$\begin{array}{l}\text { Rt } \\
(\min )\end{array}$} & \multicolumn{2}{|l|}{$m / z$} & \multirow{2}{*}{$\begin{array}{l}\text { Molecular } \\
\text { Formulab }^{b}\end{array}$} & \multirow[t]{2}{*}{ Putative Compounds ${ }^{\mathrm{b}}$} \\
\hline & & & {$[\mathrm{M}+\mathrm{H}]^{+}$} & Fragment lons & & \\
\hline \multirow[t]{6}{*}{ Excoecaria } & 1 & 0.364 & 449.1080 & $176.9858,190.9661,287.0551$ & $\mathrm{C}_{21} \mathrm{H}_{21} \mathrm{O}_{11}^{+}$ & Cyanidin 3-O-glucoside \\
\hline & 2 & 1.392 & 617.1148 & $153.0183,303.0500$ & $\mathrm{C}_{28} \mathrm{H}_{25} \mathrm{O}_{16}^{+}$ & Delphinidin 3-(2"-galloylgalactoside) \\
\hline & 3 & 1.724 & 601.1224 & $153.0181,287.0552$ & $\mathrm{C}_{28} \mathrm{H}_{25} \mathrm{O}_{15}^{+}$ & Cyanidin 3-(2"-galloylglucoside) \\
\hline & 4 & 3.034 & 595.1666 & 287.0535 & $\mathrm{C}_{27} \mathrm{H}_{31} \mathrm{O}_{15}^{+}$ & Cyanidin 3-O-rutinoside \\
\hline & 5 & 3.466 & 641.1705 & $145.0499,317.0652,443.7365,479.1180$ & $\mathrm{C}_{28} \mathrm{H}_{33} \mathrm{O}_{17}^{+}$ & Petunidin 3-sophoroside \\
\hline & 6 & 3.698 & 625.1761 & $301.0658,464.1260$ & $\mathrm{C}_{28} \mathrm{H}_{33} \mathrm{O}_{16}^{+}$ & Peonidin 3-gentiobioside \\
\hline \multirow[t]{5}{*}{ Osmanthus } & 7 & 2.399 & 595.1691 & $287.0550,449.1083$ & $\mathrm{C}_{27} \mathrm{H}_{31} \mathrm{O}_{15}^{+}$ & Cyanidin 3-O-rutinoside \\
\hline & 8 & 3.577 & 611.1626 & 303.0488 & $\mathrm{C}_{27} \mathrm{H}_{31} \mathrm{O}_{16}^{+}$ & Delphinidin 3-neohesperidoside \\
\hline & 9 & 3.626 & 889.2407 & $287.0550,581.1500$ & $\mathrm{C}_{41} \mathrm{H}_{45} \mathrm{O}_{22}^{+}$ & 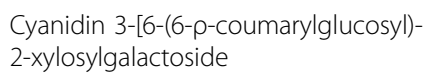 \\
\hline & 10 & 3.676 & 579.1687 & $399.1070,401.1230,417.1175$ & $\mathrm{C}_{27} \mathrm{H}_{31} \mathrm{O}_{14}^{+}$ & Pelargonidin 3-rhamnoside-5-glucoside \\
\hline & 11 & 4.207 & 449.1078 & $121.0653,137.0589,287.0553$ & $\mathrm{C}_{21} \mathrm{H}_{21} \mathrm{O}_{11}^{+}$ & Cyanidin 5-O-glucoside \\
\hline
\end{tabular}

a The compound numbers represent the main anthocyanin peaks as indicated in Fig. $2 \mathrm{C}$ and $\mathrm{D}$

b The molecular formula and the compounds were deduced based on searching the $\mathrm{m} / \mathrm{z}$ and MS/MS spectra of positive modes in "METLIN" database Rt-Retention time

$[\mathrm{M}+\mathrm{H}]^{+}$-Molecular ion

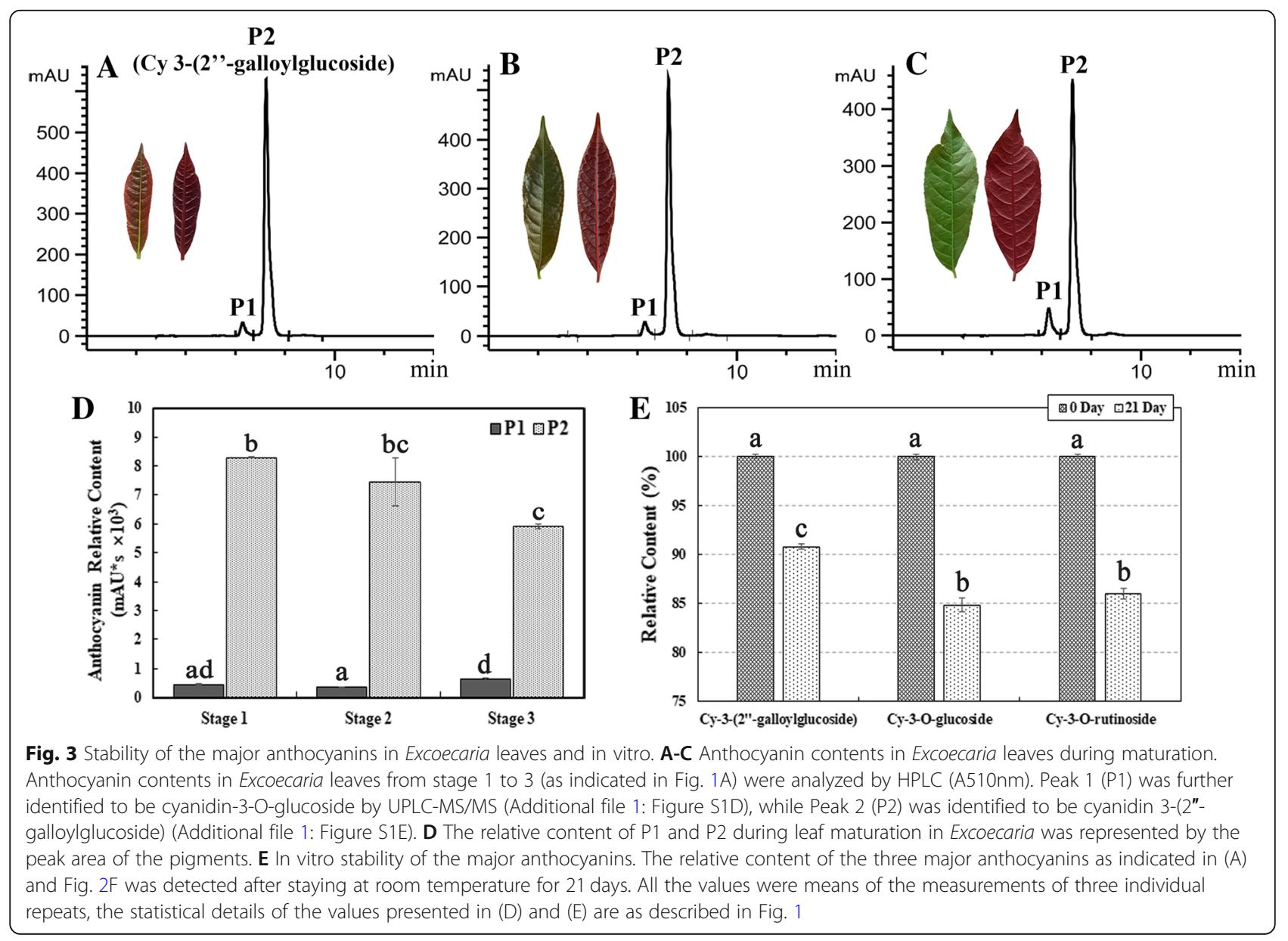


one in Osmanthus (Fig. 2D). In Excoecaria, the most abundant cyanidin 3-(2"-galloylglucoside) and a minor delphinidin 3-(2"-galloylglucoside) were galloylated anthocyanins, while only non-galloylated anthocyanins were found in Osmanthus.

\section{The galloylated anthocyanins in Excoecaria showed slightly higher stability than non-galloylated \\ anthocyanins in vitro}

The anthocyanin content in Excoecaria leaves were also measured by HPLC. Two major peaks of A510 nm, Peak 1 (P1) and Peak 2 (P2) were detected, with much higher abundance for P2 than P1 (Fig. 3A-C). The two pigment components showed marginal degradation during leaf maturation (Fig. 3D), correlating to the unchanged total anthocyanin contents during maturation in Excoecaria leaves (Fig. 1E). The anthocyanins in the two peaks were further identified by UPLC-DAD-QTOF-MS/MS, the major components in $\mathrm{P} 1$ and $\mathrm{P} 2$ were cyanidin 3-Oglucoside and cyanidin 3-(2"-galloyl- glucoside) respectively (Additional file 1: Figure S1D and E).

The above-mentioned major anthocyanins in Excoecaria, cyanidin 3-(2"-galloylglucoside) and cyanidin 3-Oglucoside, cyanidin 3-O-rutinoside in Osmanthus (Fig. 2F) were respectively purified by LH-20 column chromatography (Fig. 2A and $\mathrm{B}$ ) for stability comparison in vitro. The relative content of the three anthocyanins in $\mathrm{pH} 3.0$ buffer dropped to 91,85 and $86 \%$ respectively, in relevance to the pigment levels at day 0 , after 21 days at room temperature in vitro. Cyanidin 3-(2"-galloylglucoside) displayed slightly more stable than the other two pigments (Fig. 3E).

\section{Low $\mathrm{H}_{2} \mathrm{O}_{2}$ dependent anthocyanin degradation enzyme activity in Excoecaria leaves may be responsible for the pigment maintenance}

Anthocyanins were partially purified from the respective plants and used as substrates to detect the anthocyanin degradation enzyme (ADE) activities. Both $\mathrm{H}_{2} \mathrm{O}_{2}$ dependent and in-dependent ADE activities were monitored during leaf development (Fig. 4). The ADE activities in both plants were hardly detected without addition of $\mathrm{H}_{2} \mathrm{O}_{2}$ (Fig. 4A). When in the presence of $\mathrm{H}_{2} \mathrm{O}_{2}$, markedly higher $\mathrm{ADE}$ activities were detected for Osmanthus leaves than the activity in the absence of $\mathrm{H}_{2} \mathrm{O}_{2}$, while the ADE activity detected for Excoecaria leaves remained low even in the presence of $\mathrm{H}_{2} \mathrm{O}_{2}$ (Fig. 4B).

The ADE activity patterns were further confirmed by the in-gel activity assays using the same anthocyanin substrates, with or without $\mathrm{H}_{2} \mathrm{O}_{2}$ at $\mathrm{pH} 4.0$ (Fig. 4D and E). Correlated to the patterns, very weak $\mathrm{H}_{2} \mathrm{O}_{2}$ independent ADE activity signals were observed in the two plants while much more intensive activity staining was observed in the presence of $\mathrm{H}_{2} \mathrm{O}_{2}$ for Osmanthus. The $\mathrm{H}_{2} \mathrm{O}_{2}$ dependence of the ADE implies that the enzymes may be peroxidase (POD), correlating to the previous finding that PODs play an important role in anthocyanin degradation in planta [36]. The POD activities in the leaves were further determined by spectrophotometry (Fig. 4C) and in-gel methods (Fig. 4F). The activities detected by the two methods showed similar patterns, in which the POD activity was around 100-fold higher in Osmanthus leaves than Excoecaria. The POD activity was hardly detected using in-gel activity assay in Excoecaria at stage 1 and 2 , and weak signal at around 100 $\mathrm{kDa}$ was observed only at stage 3 , while intensive POD activity bands were detected for Osmanthus leaves at all the 3 stages (Fig. 4F). The major ADE activity band was of similar size as the POD activity band, both of around $100 \mathrm{kDa}$ (Fig. 4E and F). Together with the $\mathrm{H}_{2} \mathrm{O}_{2}$ dependence of the enzyme, the ADE was actually POD, functioning in the anthocyanin degradation in leaves, which was designated as $\mathrm{ADE} / \mathrm{POD}$ in the remainder of this article.

To better understand the maintenance of anthocyanins in Excoecaria leaves, peroxidase (ADE/POD) mediated degradation of the major Excoecaria anthocyanins were compared with the degradation of Osmanthus pigments. ADE/POD was partially purified from Osmanthus leaves by precipitation with ammonium sulfate at $70-100 \%$ saturation. In the presence of $2 \mathrm{mM} \mathrm{H}_{2} \mathrm{O}_{2}$, the partially purified $\mathrm{ADE} / \mathrm{POD}$ fraction contained high $\mathrm{ADE} / \mathrm{POD}$ activity that was visualized by in-gel activity assay, presenting as a major activity band of around $110 \mathrm{kDa}$, either with guaiacol (Fig. 4G) or Osmanthus anthocyanins as substrates (Fig. 4H). The POD fraction was therefore used for POD mediated degradation of anthocyanins identified in the two species. All the three major anthocyanins degraded rapidly after the ADE/POD was added (Fig. 4I). After $20 \mathrm{~min}$ at $25^{\circ} \mathrm{C}$, the relative content of cyanidin 3-(2"-galloylglucoside), cyanidin 3-Oglucoside and cyanidin 3-O-rutinoside, was recorded of 57, 55 and $70 \%$ as the content of the de-natured enzyme control, respectively (Fig. 4I). These results indicate that, even though the galloylated anthocyanin from Excoecaria is slightly more stable than the non-galloylated anthocyanins in vitro (Fig. 3E), the galloylated anthocyanin shows similar degradation by POD as the nongalloylated ones.

To understand the dramatical difference in ADE/POD activity between the two species, the protein levels of $\mathrm{ADE} / \mathrm{POD}$ in the leaves were immune-detected by a polyclonal POD antibody. Protein bands of around 110 $\mathrm{kDa}$ were detected by the antibody in both soluble and insoluble fractions of the protein extracts from both plants. The $110 \mathrm{kDa}$-protein showed similar levels in the soluble fractions of both plants, while higher level in the 


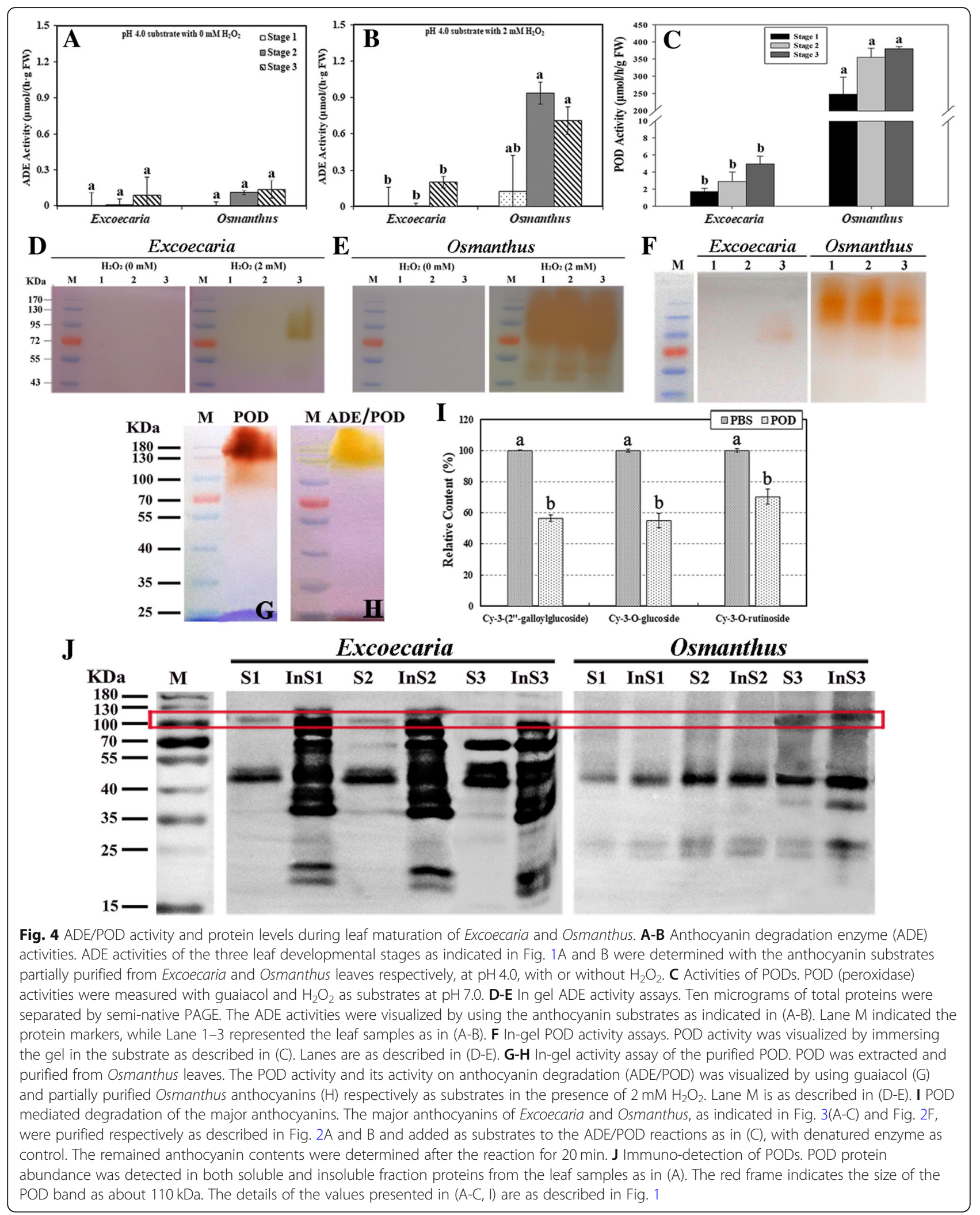


insoluble fractions were detected in Excoecaria than Osmanthus at all stages (Fig. 4J). Since 110-kDa ADE/ POD bands were both found in Excoecaria and Osmanthus, the dramatical difference in anthocyanin degradation patterns may be due to the inactivation of ADE/POD by unknown constituents in Excoecaria leaves.

\section{Natural POD inhibitors were isolated from Excoecaria leaves and constituted of galloylglucoses/ellagitannins} Phenolics in Excoecaria leaves were extracted and separated by Sephadex LH-20 column chromatography, so as to investigate whether natural POD inhibitors exist in the leaves. Fifteen fractions were obtained based on A280 nm peaks (Fig. 5A) and the phenolic content of each fraction was determined as gallic acid equivalent (GAE). The inhibition effects of $100 \mu \mathrm{M}$ GAE of each fraction were investigated on the ADE/POD activity (Fig. 4G). Among these fractions and GA, F1, F2, F13, F14 and GA showed more than $50 \%$ inhibition rate, with $52.45,77.22,64.31,66.08$ and $83.36 \%$ inhibition respectively (Fig. 5B). The half maximal inhibitory concentration (IC50) values of GA, F1, F2, F13 and F14 on ADE/ POD were estimated as $35.55,82.92,67.24,81.56$ and 83.27 $\mu \mathrm{M}$ GAE respectively, indicating the phenolic fractions from Excoecaria leaves contained natural ADE/ POD inhibitors.

The compounds in the F1, F2, F13 and F14 fraction were further analyzed by UPLC-DAD-QTOF-MS/MS (Table 2 and Fig. 5D-G). Based on the fragment ions in the MS/MS graphs in negative modes (Additional file 2: Figure S2), GA fragments (78.01, 125.02 and 169.01) and HHDP (hexahydroxydiphenoyl) unit (300.99) were detected in the compounds of the 4 fractions, indicating the compounds are GA or HHDP derivatives (Table 2; Additional file 2: Figure S2). The major compounds in F1, both Cpd 1 and 2 were monogalloylglucose with mass of $332 \mathrm{Da}$. Both Cpd 3 and 4 in F2 were galloyl quinic acid with mass of $344 \mathrm{Da}$. In F13, Cpd 5 was identified as methyl gallic acid with mass of $184 \mathrm{Da}$, Cpd 6,7 and 8 , were identified as three ellagitannins (HHDP derivatives, with mass of 952, 1104, $1118 \mathrm{Da}$ respectively). Five compounds were identified in F14, including Cpd 9, another methyl gallic acid with mass of $184 \mathrm{Da}$; another two ellagitannins (Cpd 10 and 11, with mass of 952 and $966 \mathrm{Da}$ respectively); two galloylglucoses (simple gallic acid derivatives), tetragalloyl hexoside (Cpd 12) and pentagalloyl hexoside (Cpd 13) (Table 2). Taken together, even though further identification of the compounds by other methods is required, the existence of galloyl/HHDP-moiety was confirmed in the major compounds of the fractions, indicating high levels of GGs/ETs in the phenolic fractions are responsible for the POD inhibition.

\section{More hydrolysable tannins were identified in Excoecaria} but not in Osmanthus leaves

Prompted by the multiple GGs/ETs found in the phenolic fractions with high inhibitory efficacy on POD, we compared the phenolic compound profiling between Excoecaria and Osmanthus leaves by UPLC-DADQTOF-MS/MS analysis. The chromatogram profiles showed around 25 and 19 peaks of the absorbance at $280 \mathrm{~nm}$ in leaf extracts of Excoecaria and Osmanthus respectively (Fig. 6A and C). The detected compounds whose MS/MS spectra were successfully acquired and of high A280nm were subjected for alignment with the information obtained in Metlin databases (https://metlin. scripps.edu/), Chemspider (http://www.chemspider.com/) and Pubchem (https://pubchem.ncbi.nlm.nih.gov/). In Excoecaria, gallic acid (Cpd 3) and ellagic acid (Cpd 20) were identified with $[\mathrm{M}-\mathrm{H}]^{-}$ion at $\mathrm{m} / \mathrm{z} 169.0136$ and 300.9986 respectively, with characteristic daughter ion at $\mathrm{m} / \mathrm{z} 125.0235$ and 283.9956 respectively. Among the 25 identified compounds, 17 compounds (Cpd 1, 2, 3, 4, 6, 7, $9,10,11,14,15,17,18,19,20,21,24)$ were detected of fragments at m/z 169.0136 or 125.0235 or 300.9991 . Together with the MS and MS/MS spectra alignments with the information obtained from the above-mentioned databases (Additional file 4: Data file 1), these compounds were predicted to be gallic acid, ellagic acid or HHDP derivatives, most of them were predicted to be GGs/ETs with galloyl (Cpd 1, 2, 4, 6, 9, 10, 14, 15, 17, 18, 19, 21, 24) or/and HHDP units (Cpd 1, 9, 11, 14), bounded to sugar moiety (Fig. 6B). Among the simple gallic acid derivatives or ellagitannins, high levels of ellagitannins (Cpd 1, 14), pentagalloyl hexoside (Cpd 2, 18) and tetragalloyl hexoside (Cpd 15) were also found in the Excoecaria fractions of high inhibitory efficacy on POD (Fig. 6B; Table 2). Compared to Excoecaria, hydrolysable tannins were not found in Osmanthus (Additional file 5: Data file 2). In contrast, some lignin constitutes, such as cinnamate in compound 1 ; coumaroyl in compound 4, 5 and 8; and caffeoyl in compound 7 were identified in Osmanthus (Fig. 6D).

\section{High levels of hydrolysable tannins co-localized with anthocyanins in Excoecaria inhibited the in vivo POD activity and increased the color intensity by copigmentation}

Most of the identified phenolics in Excoecaria, particularly for those of high POD inhibitory efficacy, were GGs/ETs belonging to hydrolysable tannins (Table 2 and Fig. 6B). Therefore, total tannin contents were determined in Excoecaria and Osmanthus leaves during leaf development. Increased tannin contents were found in Excoecaria along with the leaf maturation, while the content in Osmanthus leaves decreased during the process. Five folds higher tannin contents were detected in Excoecaria leaves than Osmanthus leaves at stage 2, 

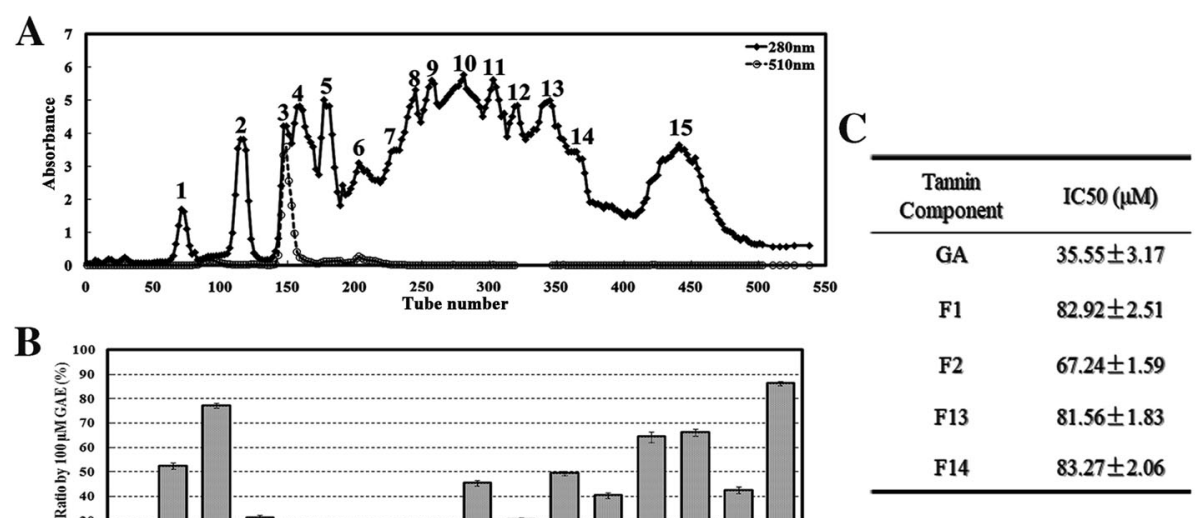

B
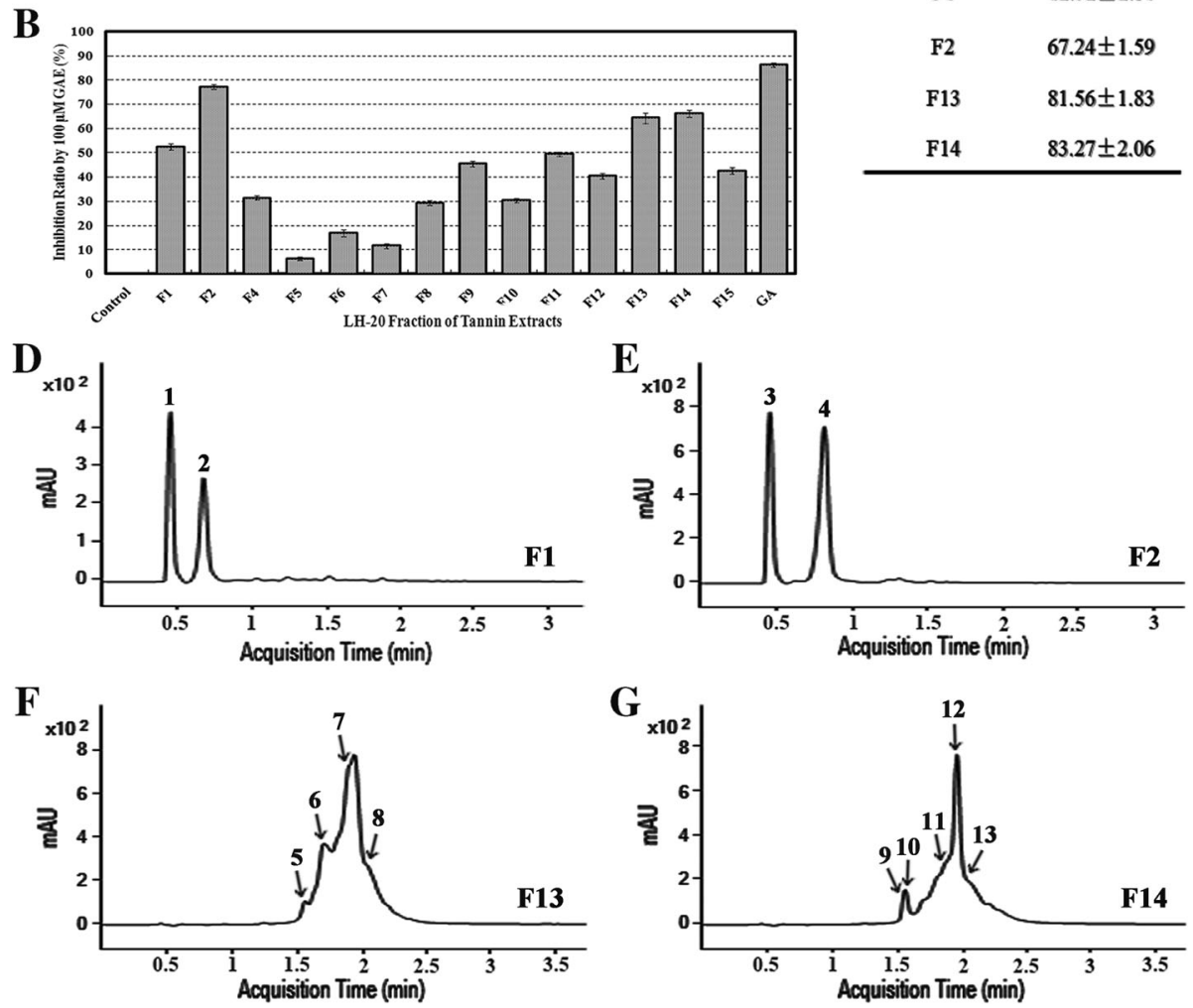

Fig. 5 Isolation of natural POD inhibitors from Excoecaria leaves. A Separation of phenolic compounds from the Excoecaria leaf by Sephadex LH 20 column chromatography. Fifteen fractions were obtained based on the absorbance peaks at $280 \mathrm{~nm}$ of the chromatography profile. B The inhibition of the phenolic fractions on POD activity. The inhibition ratio on the POD activity indicated in Fig. 4G was measured by the addition of $100 \mu \mathrm{M}$ GAE (gallic acid equivalent) of each fraction (A) to the activity assay reaction as described in Fig. 4C. C IC50 values of the fractions on POD. The half maximal inhibitory concentration (IC50) values of the fractions (F1, F2, F13, F14), which showed more than 50\% inhibition on the POD activity as indicated in (B) and regarded to be of high inhibitory efficacy, were measured with gallic acid as a reference. D-G UPLC-DAD profiles of the high inhibition fractions represented by absorbance at $280 \mathrm{~nm}$. The high inhibition fractions from Excoecaria leaves as indicated in (C) were respectively analyzed by UPLC-DAD

with 49.94 and $7.14 \mathrm{mg}$ TAE/g FW, respectively (Fig. 7K) . High content of GA was detected in Excoecaria leaves at all stages, ranged between 0.55 to $1.01 \mathrm{mg} / \mathrm{g} \mathrm{DW}$. However, GA was not detected in Osmanthus at all the stages (Fig. 7L; Additional file 3: Figure S3).

The location of tannins in the leaves were observed by ruthenium red and toluidine blue staining. Strong pinkred staining was observed in 7-8 cell layer of the abaxial surface of Excoecaria, but not in Osmanthus cells (Fig. 7C and D), indicating high content of tannins accumulated in Excoecaria leaves. To better understand the levels of hydrolysable tannins in the leaf tissue, vanillin staining of condensed tannins (PAs) was carried out.
Light brown staining was observed only in 2-3 cell layer of the abaxial surface of Excoecaria, but not in Osmanthus cells (Fig. 7E and F). The above result revealed large amount of hydrolysable tannins accumulated at the abaxial surface of Excoecaria leaves while none was in Osmanthus leaves. The result of frozen sections showed that anthocyanins were mainly located at the abaxial surface of Excoecaria leaves at the three stages (Fig. 1C, Fig. 7A), unlike the even distribution of anthocyanins at both the adaxial/abaxial surface of Osmanthus leaves at stage 1 and 2 (Fig. 1D, Fig. 7B). Furthermore, when leaf blade sections were incubated with POD substrates, dark-brown color appeared at the 
Table 2 Identification of the main POD inhibitors from Excoecaria leaves by UPLC-DAD-QTOF-MS/MS

\begin{tabular}{|c|c|c|c|c|c|c|c|c|}
\hline \multirow[t]{2}{*}{ Fraction $^{a}$} & \multirow{2}{*}{$\begin{array}{l}\text { Compound } \\
\text { No. }{ }^{b}\end{array}$} & \multirow[t]{2}{*}{$\mathrm{Rt}(\mathrm{min})$} & \multirow{2}{*}{$\begin{array}{l}\text { Molecular } \\
\text { Formula }^{c}\end{array}$} & \multirow{2}{*}{$\begin{array}{l}\text { Molecular } \\
\text { Mass }\end{array}$} & \multirow{2}{*}{$\begin{array}{l}\Delta \text { mass } \\
(\mathrm{ppm})\end{array}$} & \multicolumn{2}{|l|}{$\mathrm{m} / \mathrm{z}$} & \multirow[t]{2}{*}{ Putative Name ${ }^{c}$} \\
\hline & & & & & & {$[\mathrm{M}-\mathrm{H}]^{-}$} & Fragment lons & \\
\hline \multirow[t]{2}{*}{$\mathrm{F} 1$} & 1 & 0.509 & $\begin{array}{l}\mathrm{C}_{13} \mathrm{H}_{16} \\
\mathrm{O}_{10}\end{array}$ & 332.0754 & 3.05 & 331.0682 & $\begin{array}{l}\text { 151.0030; 169.0135; 211.0233; } \\
331.0616\end{array}$ & $\begin{array}{l}\text { Galloyl hexoside [49] } \\
\text { (Monogalloylglucose) }\end{array}$ \\
\hline & 2 & 0.726 & $\begin{array}{l}\mathrm{C}_{13} \mathrm{H}_{16} \\
\mathrm{O}_{10}\end{array}$ & 332.0745 & 0.59 & 331.0673 & $\begin{array}{l}\text { 151.0032; 169.0135; 211.0235; } \\
331.0642\end{array}$ & $\begin{array}{l}\text { Galloyl hexoside [49] } \\
\text { (Monogalloylglucose) }\end{array}$ \\
\hline \multirow[t]{2}{*}{ F2 } & 3 & 0.517 & $\begin{array}{l}\mathrm{C}_{14} \mathrm{H}_{16} \\
\mathrm{O}_{10}\end{array}$ & 344.0748 & 1.41 & 343.0676 & $\begin{array}{l}\text { 125.0250; 169.0137; 191.0552; } \\
343.0642\end{array}$ & Galloyl quinic acid [49] \\
\hline & 4 & 0.859 & $\begin{array}{l}\mathrm{C}_{14} \mathrm{H}_{16} \\
\mathrm{O}_{10}\end{array}$ & 344.0749 & 1.49 & 343.0676 & $\begin{array}{l}\text { 127.0398; 169.0136; 191.0549; } \\
343.0642\end{array}$ & Galloyl quinic acid [49] \\
\hline \multirow[t]{4}{*}{ F13 } & 5 & 1.629 & $\mathrm{C}_{8} \mathrm{H}_{8} \mathrm{O}_{5}$ & 184.0375 & 1.99 & 183.0303 & $\begin{array}{l}\text { 78.0112;124.0168; 153.0219; } \\
168.0070\end{array}$ & Methyl gallic acid \\
\hline & 6 & 1.724 & $\begin{array}{l}\mathrm{C}_{41} \mathrm{H}_{28} \\
\mathrm{O}_{27}\end{array}$ & 952.0814 & 0.38 & 951.0738 & $\begin{array}{l}\text { 300.9991; 461.0359; 583.0310; } \\
933.0622\end{array}$ & $\begin{array}{l}\text { Ellagitannin } \\
\text { (HHDP derivative [49]) }\end{array}$ \\
\hline & 7 & 1.855 & $\begin{array}{l}\mathrm{C}_{55} \mathrm{H}_{28} \\
\mathrm{O}_{26}\end{array}$ & 1104.0936 & 0.76 & 1103.0859 & $\begin{array}{l}\text { 300.9992; 445.0416; 631.0566; } \\
951.0722\end{array}$ & $\begin{array}{l}\text { Ellagitannin [50] } \\
\text { (HHDP derivative) }\end{array}$ \\
\hline & 8 & 2.002 & $\begin{array}{l}\mathrm{C}_{56} \mathrm{H}_{30} \\
\mathrm{O}_{26}\end{array}$ & 1118.1099 & 6.57 & 1117.1012 & $\begin{array}{l}\text { 166.9995; 300.9995; 461.0346; } \\
965.0902\end{array}$ & $\begin{array}{l}\text { Ellagitannin [50] } \\
\text { (HHDP derivative) }\end{array}$ \\
\hline \multirow[t]{5}{*}{ F14 } & 9 & 1.608 & $\mathrm{C}_{8} \mathrm{H}_{8} \mathrm{O}_{5}$ & 184.0373 & 0.5 & 183.0560 & $\begin{array}{l}\text { 78.0109;124.0164; 153.0175; } \\
168.0058\end{array}$ & Methyl gallic acid \\
\hline & 10 & 1.612 & $\begin{array}{l}\mathrm{C}_{41} \mathrm{H}_{28} \\
\mathrm{O}_{27}\end{array}$ & 952.0819 & 0.16 & 951.0747 & $\begin{array}{l}\text { 169.0143; 300.9993; 461.0390; } \\
933.0627\end{array}$ & $\begin{array}{l}\text { Ellagitannin } \\
\text { (Galloyl HHDP derivative [49] }\end{array}$ \\
\hline & 11 & 1.862 & $\begin{array}{l}\mathrm{C}_{42} \mathrm{H}_{30} \\
\mathrm{O}_{27}\end{array}$ & 966.097 & 0.51 & 965.0897 & $\begin{array}{l}\text { 300.9994; 461.0401; 805.9860; } \\
933.0648\end{array}$ & $\begin{array}{l}\text { Ellagitannin [50] } \\
\text { (HHDP derivative) }\end{array}$ \\
\hline & 12 & 1.885 & $\begin{array}{l}\mathrm{C}_{34} \mathrm{H}_{28} \\
\mathrm{O}_{22}\end{array}$ & 788.1076 & 0.42 & 787.1003 & $\begin{array}{l}\text { 169.0143; 465.0666; 573.0867; } \\
617.0789\end{array}$ & $\begin{array}{l}\text { Tetragalloyl hexoside } \\
\text { (Tetragalloyl glucose) [49] }\end{array}$ \\
\hline & 13 & 2.017 & $\begin{array}{l}\mathrm{C}_{41} \mathrm{H}_{32} \\
\mathrm{O}_{26}\end{array}$ & 940.1182 & 3.83 & 939.1110 & $\begin{array}{l}\text { 125.0247; 169.0146; 465.0682; } \\
617.0791\end{array}$ & $\begin{array}{l}\text { Pentagalloyl hexoside } \\
\text { (Pentagalloyl glucose) [49] }\end{array}$ \\
\hline
\end{tabular}

\footnotetext{
a The fractions were of high inhibitory efficacy on POD as indicated in Fig. 5B

b The compound numbers represent the main peaks as indicated in Fig. 5D-G

"The molecular formula and the compounds were deduced based on searching the $\mathrm{m} / \mathrm{z}$ and MS/MS spectra of negative modes in "METLIN" database HHDP-Hexahydroxydiphenoyl unit

Rt-Retention time

$[\mathrm{M}-\mathrm{H}]^{-}-$Molecular ion
}

cells of both adaxial and abaxial surface in Osmanthus (Fig. 7H); while in Excoecaria leaves, browning was less intensive than in Osmanthus and only appeared at the adaxial surface (Fig. 7G). The results indicate that high POD activity was found for both sides of the leaves in Osmanthus, while the activity was hardly detected at the abaxial surface of Excoecaria leaves, correlating with the high level of tannins locating at the abaxial side of the leaves (Fig. 7C-J).

The copigmentation of hydrolysable tannins and anthocyanins were also investigated. After $0-300 \mu \mathrm{g} / \mathrm{mL}$ GAE of GA or the fractions (F1, F2, F13, F14) (Table 2) were added to Excoecaria and Osmanthus anthocyanin solutions $(0.05 \mathrm{mM})$ at $\mathrm{pH} 3.0$, significant increase in red color intensities of the solutions were observed (Fig. 7M-O), indicating copigmentation occurred between the GGs/ETs and anthocyanins. GGs/ETs produced more profound effect on the red color of cyanidin 3-O-rutinoside and cyanidin 3-O-glucoside than on the color of cyanidin 3(2"-galloyl-glucoside) (Fig. 7M-O). F13 and F14, which contained high levels of GGs/ETs (Fig. 5F and G, Table 2), produced more enhancement in the color intensity than F1, F2 and GA (Fig. 7M-O). Addition of $300 \mu \mathrm{g} / \mathrm{mL}$ GAE F13 and F14 respectively led to 30.88 and $17.09 \%$ higher absorbance at $510 \mathrm{~nm}$ (A510 nm) for cyanidin 3-Orutinoside (Fig. 7O); 34.57 and $20.83 \%$ higher $A 510 \mathrm{~nm}$ for cyanidin 3-O-glucoside (Fig. 7N), 11.67 and $7.99 \%$ higher A510nm for cyanidin 3-(2"-galloylglucoside) (Fig. 7M).

Taken together, high levels of hydrolysable tannins were found to be co-localized with the anthocyanins at the abaxial surface of Excoecaria leaves, which significantly enhanced the color of the pigments and reduced the activity of the anthocyanin degradation related POD.

\section{High levels of hydrolysable tannins led to low $\mathrm{pH}$ values at the abaxial surface of Excoecaria leaves}

Since the stability of anthocyanins is also dependent on the $\mathrm{pH}$ values of cells, the $\mathrm{pH}$ values in both plants were measured. Around 4.0 to $4.5 \mathrm{pH}$ values were recorded in Excoecaria leaves, which were lower than the 5.5 to 6 


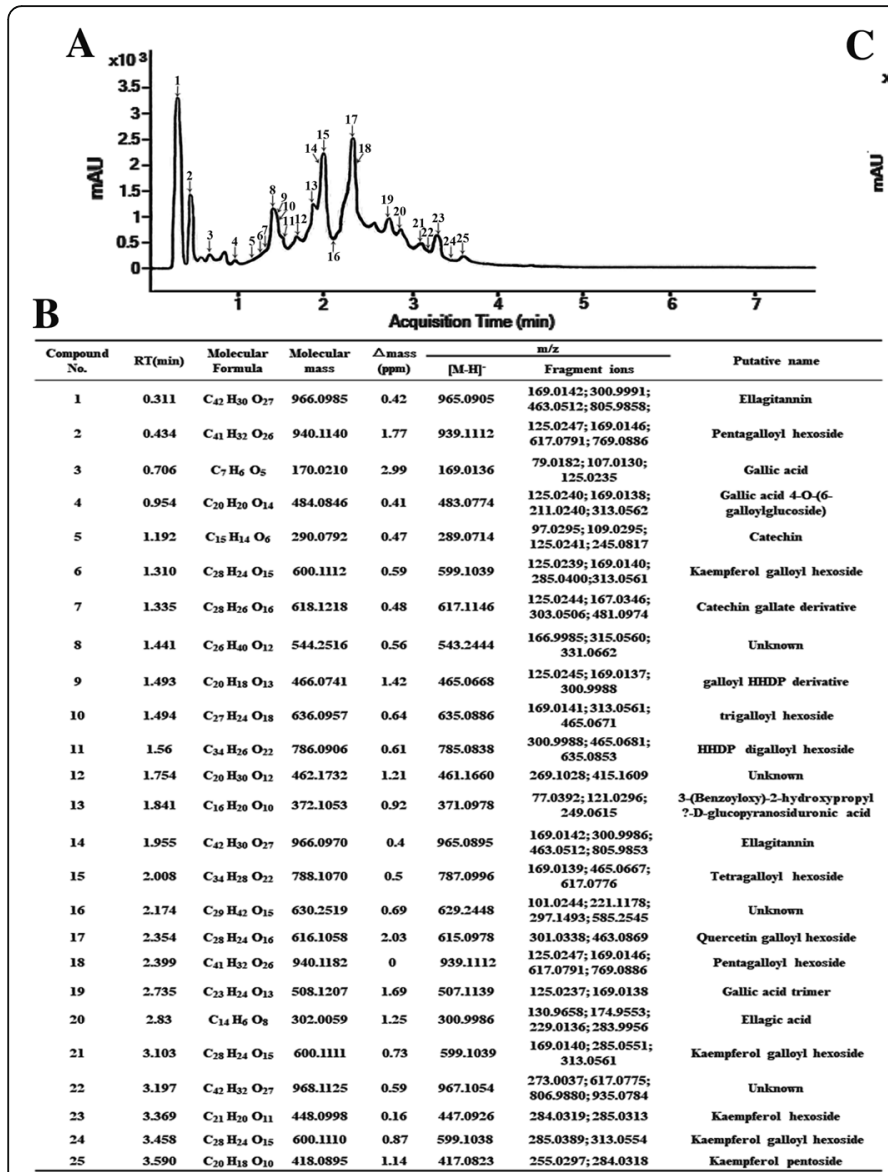

C

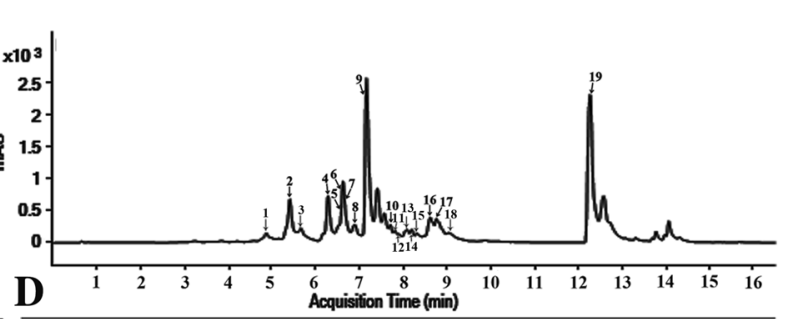

\begin{tabular}{|c|c|c|c|c|c|c|c|}
\hline \multirow[b]{2}{*}{$\begin{array}{c}\text { Compound } \\
\text { No. }\end{array}$} & \multirow[b]{2}{*}{$\mathbf{R T}($ min) } & \multirow[b]{2}{*}{$\begin{array}{c}\text { Molecular } \\
\text { Formula }\end{array}$} & \multicolumn{4}{|c|}{ Acquisition Time (min) } & \multirow[b]{2}{*}{ Putative name } \\
\hline & & & $\begin{array}{c}\text { Molecular } \\
\text { mass }\end{array}$ & $\begin{array}{l}\Delta \text { mass } \\
(\mathrm{ppm})\end{array}$ & {$[\mathbf{M}-\mathbf{H}]^{-}$} & $\begin{array}{l}\mathrm{m} / \mathrm{z} \\
\text { Fragment ions }\end{array}$ & \\
\hline 1 & 4.931 & $\mathrm{C}_{15} \mathrm{H}_{18} \mathrm{O}_{8}$ & 326.1002 & 0.2 & 325.0930 & $\begin{array}{c}117.0346 ; 145.0294 ; \\
265.0722\end{array}$ & $\begin{array}{l}\text { cis-p-D-Glucosyl-2- } \\
\text { hydroxycinnamate }\end{array}$ \\
\hline 2 & 5.407 & $\mathrm{C}_{39} \mathrm{H}_{52} \mathrm{O}_{25}$ & 920.2801 & 0.37 & 919.2728 & $\begin{array}{c}161.0241 ; 191.0562 \\
353.0885\end{array}$ & Cassiaside B2 \\
\hline 3 & 5.716 & $\mathrm{C}_{16} \mathrm{H}_{18} \mathrm{O}_{9}$ & 354.0954 & 0.93 & 353.0878 & $\begin{array}{l}\text { 160.0168; } 191.0559 ; \\
\text { 235.0611;353.0880 }\end{array}$ & Scopolin \\
\hline 4 & 6.336 & $\mathrm{C}_{16} \mathrm{H}_{18} \mathrm{O}_{8}$ & 338.0999 & 0.82 & 337.0926 & $\begin{array}{l}\text { 93.0346; 163.0397; } \\
191.0559 ; 337.0925\end{array}$ & Coumaroyl quinic acid \\
\hline 5 & 6.581 & $\mathrm{C}_{16} \mathrm{H}_{18} \mathrm{O}_{8}$ & 338.1012 & 2.91 & 337.0940 & $\begin{array}{l}\text { 93.0346; 163.0397; } \\
191.0559 ; 337.0925\end{array}$ & Coumaroyl quinic acid \\
\hline 6 & 6.648 & $\mathrm{C}_{33} \mathrm{H}_{33} \mathrm{O}_{17}$ & 706.2116 & 1.05 & 705.2044 & $\begin{array}{l}\text { 93.0348; 191.0562; } \\
\mathbf{3 3 7 . 0 9 3 2 ; 3 6 7 . 1 0 4 0}\end{array}$ & Unknown \\
\hline 7 & 6.718 & $\mathbf{C}_{17} \mathbf{H}_{20} \mathbf{O}_{9}$ & 368.1115 & 2.13 & 367.1034 & $\begin{array}{c}\text { 93.0349; 191.0566; } \\
367.1037\end{array}$ & Caffeoyl methylquinic acid \\
\hline 8 & 6.81 & $\mathrm{C}_{16} \mathrm{H}_{18} \mathrm{O}_{8}$ & 338.1004 & 0.55 & 337.0931 & $\begin{array}{l}\text { 93.0346; } 163.0397 ; \\
\text { 191.0559;337.0925 }\end{array}$ & Coumaroyl quinic acid \\
\hline 9 & 7.188 & $\mathrm{C}_{29} \mathrm{H}_{37} \mathrm{O}_{15}$ & 625.2092 & - & 624.2021 & & Flupenthixol-0-glucuronide \\
\hline 10 & 7.704 & $\mathrm{C}_{26} \mathrm{H}_{32} \mathrm{O}_{14}$ & 568.1794 & 0.39 & 567.1722 & & Piceatannol 3,4'-diglucoside \\
\hline 11 & 7.794 & $\mathrm{C}_{27} \mathrm{H}_{30} \mathrm{O}_{16}$ & 610.1537 & 0.54 & 609.1464 & 300.0262 & Rutin \\
\hline 12 & 7.886 & $\mathrm{C}_{29} \mathrm{H}_{36} \mathrm{O}_{15}$ & 624.2059 & 0.74 & 623.1988 & $\begin{array}{l}\text { 113.0242; } 161.0242 ; \\
\text { 315.1106; } 461.1671\end{array}$ & Isoacteoside \\
\hline 13 & 8.058 & $\mathrm{C}_{27} \mathrm{H}_{30} \mathrm{O}_{16}$ & 610.1536 & 0.35 & 609.1463 & 300.0262 & Herbacetin 8-rutinoside \\
\hline 14 & 8.175 & $\mathrm{C}_{27} \mathrm{H}_{30} \mathrm{O}_{15}$ & 594.1586 & 0.22 & 593.1513 & & Luteolin 7-neohesperidoside \\
\hline 15 & 8.267 & $\mathrm{C}_{27} \mathrm{H}_{34} \mathrm{O}_{15}$ & 598.1902 & 0.8 & 597.1831 & $\begin{array}{l}\text { 89.0246; 139.0034; } \\
\text { 239.0559;375.1082 }\end{array}$ & 10-Acetoxyoleuropein \\
\hline 16 & 8.635 & $\mathrm{C}_{25} \mathrm{H}_{23} \mathrm{O}_{10}$ & 488.1686 & 0.64 & 487.1613 & $\begin{array}{c}119.0497 ; 145.0292 \\
163.0600\end{array}$ & Egonol glucoside \\
\hline 17 & 8.753 & $\mathrm{C}_{21} \mathrm{H}_{20} \mathrm{O}_{11}$ & 448.1006 & 0.1 & 447.0933 & - & Luteolin 5 -glucoside \\
\hline 18 & 9.132 & $\mathrm{C}_{27} \mathrm{H}_{\mathcal{H}} \mathrm{O}_{14}$ & 582.1958 & 1.6 & 581.1887 & $\begin{array}{l}\text { 101.0248; 291.0882; } \\
\text { 359.1141;521.1662 }\end{array}$ & 10-Acetoxyligustroside \\
\hline 19 & 12.318 & $\mathrm{C}_{30} \mathrm{H}_{48} \mathrm{O}_{5}$ & 488.3502 & 0.04 & 487.3429 & $\begin{array}{c}69.0699 ; 425.3403 ; \\
473.3260\end{array}$ & Madasiatic acid \\
\hline
\end{tabular}

Fig. 6 Non-targeted phenolic compound analysis of the leaves of Excoecaria and Osmanthus by UPLC-DAD-QTOF-MS/MS. A UPLC-DAD profiles $(A 280 \mathrm{~nm})$ of the phenolic extract from Excoecaria leaves. Phenolic compounds were extracted from the Excoecaria leaves at stage 2 and subjected to UPLC-DAD-QTOF-MS/MS analysis. The peaks including the main phenolic compounds in (B) were numbered from 1 to 25. B Identification of the main phenolic compounds in Excoecaria leaves. The compounds in the extract were identified based on the MS and MS/MS spectra (Additional file 4: Data file 1), details are as described in Table 2. C UPLC-DAD profiles (A280 nm) of the phenolic extract from Osmanthus leaves. Total phenolic compounds were extracted from the Osmanthus leaves at stage 2 and subjected to UPLC-DAD-QTOF-MS/MS analysis. The peaks including the main phenolic compounds in (D) were numbered from 1 to 19. D Identification of the main phenolic compounds in Osmanthus leaves. The compounds in the extract were identified based on the MS and MS/MS spectra (Additional file 5: Data file 2), details are as described in Table 2

$\mathrm{pH}$ values detected in Osmanthus leaves (Fig. 8A). The in vivo vacuole acidity of the epidermal cells was further measured by Neutral Red (NR) staining (Fig. 8B-Q). After staining, red coloration was only observed in the abaxial epidermal cells of Excoecaria leaves (Fig. 8G and O) while red coloration was observed in the epidermal cells at both sides of Osmanthus leaves (Fig. 8E, I, M and Q). The stained cells in Excoecaria exhibited much stronger accumulation of NR than the cells in Osmanthus (Fig. 8G, O, I and Q), indicating these Excoecaria cells were in a more acidic environment, which were expected to increase the stability of anthocyanin.

\section{Discussion}

In general, anthocyanins are transiently accumulated in young leaves to protect the tissue from light damage, and the pigments are rapidly degraded after leaf maturation or in shape [1]. However, in some shape understorey plants, such as Tradescantia [51], Begonia [23], Cyclamen [22], and Excoecaria [47], anthocyanins are still maintained in the abaxial leaves after maturation, even in low light conditions $[21,52]$. Anthocyanin maintenance in the abaxial surface of mature leaves plays important photoprotection roles for these understorey plants, while the mechanism of the anthocyanin maintenance is still unclear. In the present study, to investigate the potential factors in leaves that may prevent the anthocyanins from degradation in abaxially red leaves, we compared anthocyanin enzymatic degradation and the phenolic metabolites between a permanent pigmentation plant (Excoecaria) and a transient pigmentation plant (Osmanthus). 


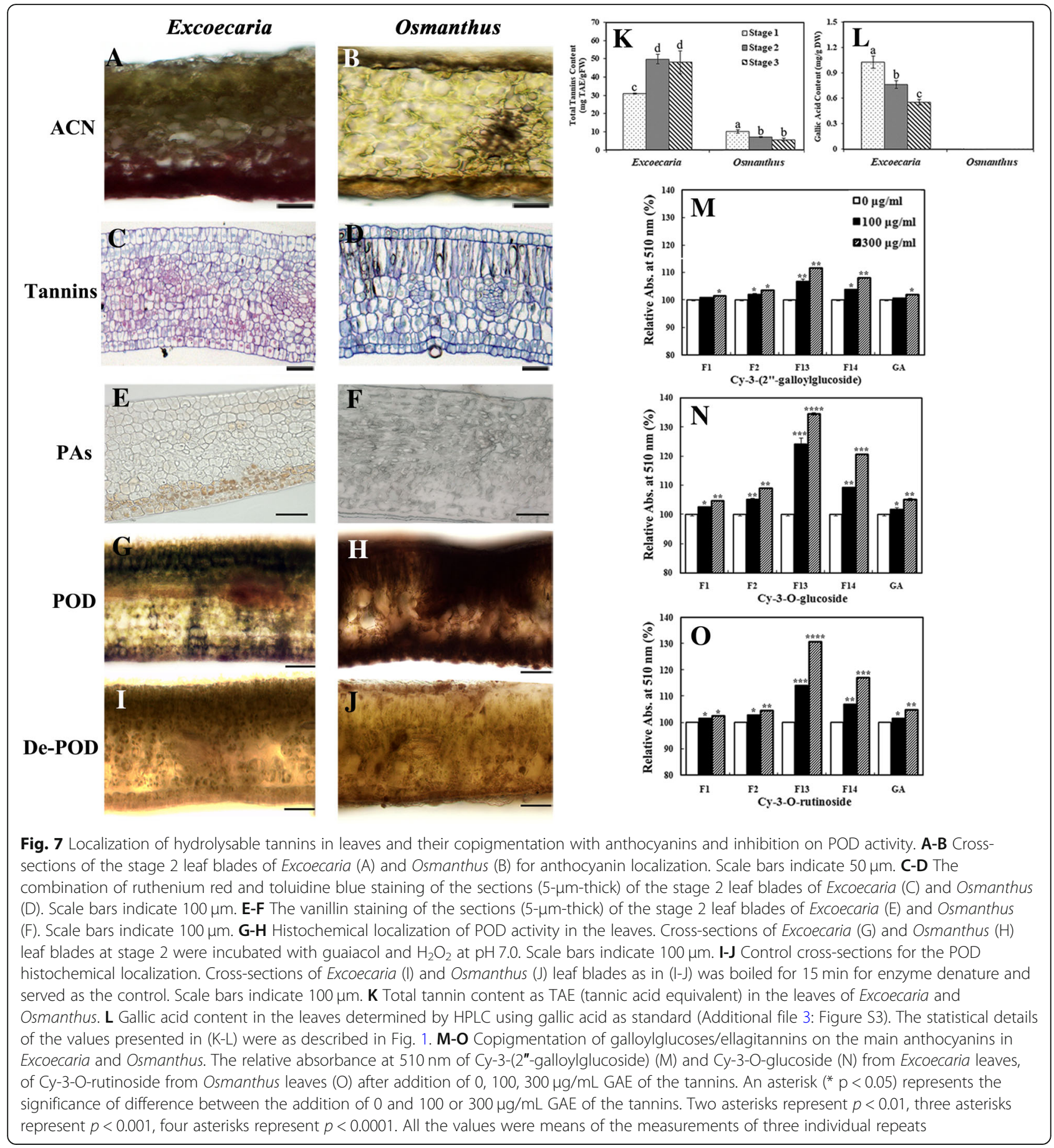

We first investigated whether the permanent and transient pigmentation in the Excoecaria and Osmanthus leaves respectively was due to the different type of anthocyanins. Indeed, we found high level of galloylated anthocyanins (anthocyanins acylated with gallic acid) in Excoecaria while all the pigments in Osmanthus are non-galloylated (Table 1, Fig. 2E and F). Galloylated anthocyanins were also found in red leaves of Acer platanoides "Crimson King" [53], red flowers of chenille plant, Acalypha hispida Burm. [54]. It has been reported that the anthocyanins carrying aromatic acyl substituents including $p$-coumaric, caffeic, ferulic, sinapic, gallic or $p$ hydroxybenzoic acids, displayed great stability due to intramolecular copigmentation [55-57]. Furthermore, acylated anthocyanins were reported to represent a much more efficient means of photoprotection by providing the plants with ultrafast energy dissipation and significant UV-B absorption capacity [58]. In the present 

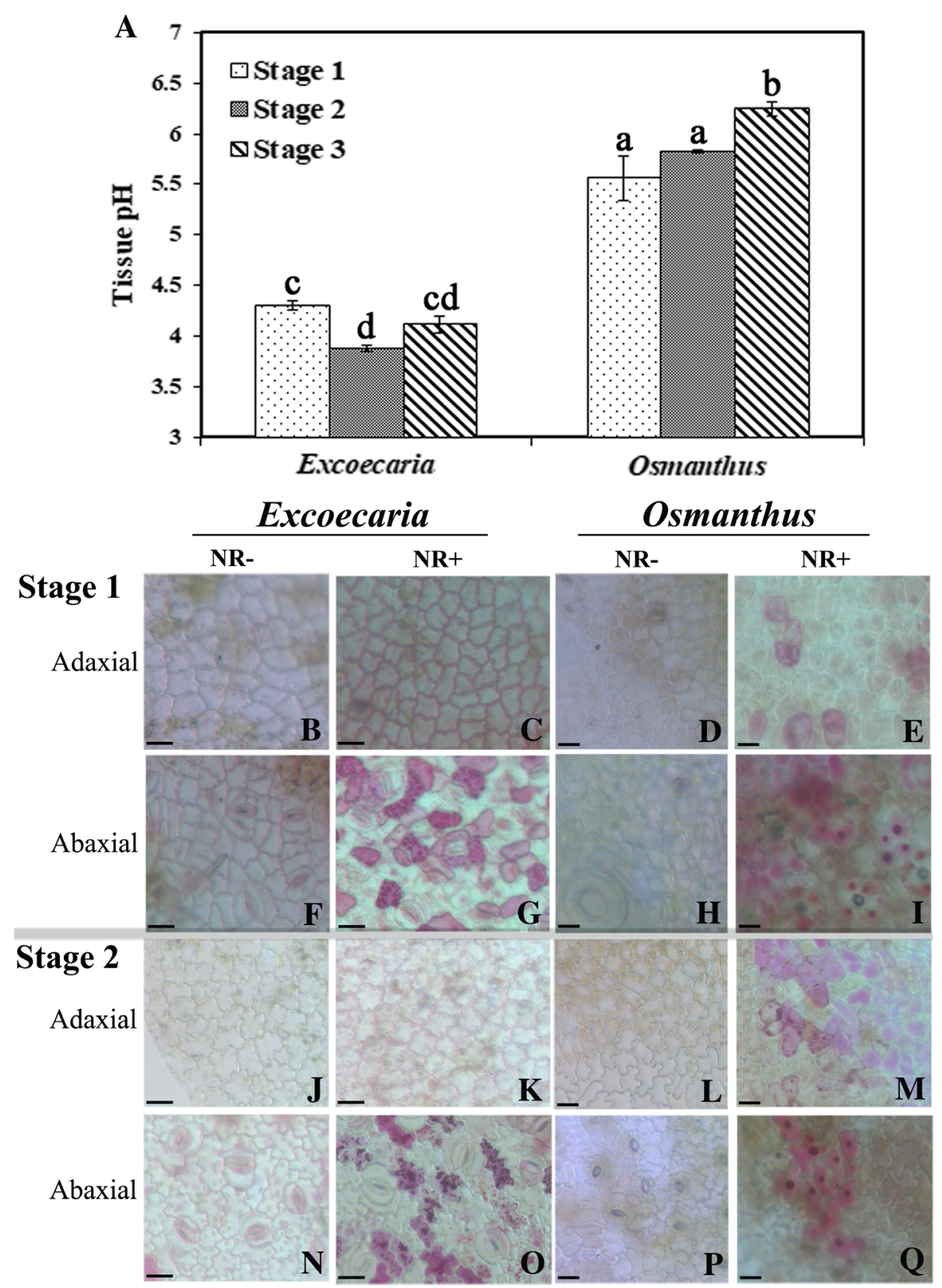

Fig. $8 \mathrm{pH}$ values of Excoecaria and Osmanthus leaves. (A) The pH values of the homogenate of Excoecaria and Osmanthus leaves in water. The details of the leaf developmental stages are as described in Fig. 1. B-C, J-K Neutral Red staining of the adaxial epidermal cells of Excoecaria leaves. The adaxial epidermal cells of Excoecaria leaves without Neutral Red (-NR) staining at stage 1 (B), stage $2(J)$ and with NR (+NR) staining at stage $1(\mathrm{C})$, stage $2(\mathrm{~K})$. F-G, N-O NR staining of the abaxial epidermal cells of Excoecaria leaves. The abaxial epidermal cells of Excoecaria leaves without NR staining at stage $1(\mathrm{~F})$, stage $2(\mathrm{~N})$ and with NR staining at stage $1(\mathrm{G})$, stage $2(\mathrm{O})$. D-E, L-M NR staining of the adaxial epidermal cells of Osmanthus leaves. The adaxial epidermal cells of Osmanthus leaves without NR staining at stage $1(\mathrm{D})$, stage $2(\mathrm{~L})$ and with NR staining at stage 1 (E), stage 2 (M). $\mathbf{H}-\mathbf{I}, \mathbf{P}-\mathbf{Q}$ NR staining of the abaxial epidermal cells of Osmanthus leaves. The abaxial epidermal cells of Osmanthus leaves without NR staining at stage $1(H)$, stage $2(P)$ and with NR staining at stage $1(I)$, stage $2(Q)$. Scale bars indicate $30 \mu \mathrm{m}$

study, cyanidin 3-(2"-galloylglucoside) was found to be more stable than cyanidin 3-O-rutinoside and cyanidin 3-O-glucoside (Fig. 3E). However, both galloylated and non-galloylated anthocyanins isolated from Excoecaria and Osmanthus respectively degraded rapidly in the presence of peroxidase (POD) (Fig. 4I). Considering enzymatic degradation may play more significant role than spontaneous breakdown in vivo tissue $[35,36]$, we speculated that other factors, rather than the stability of the pigments, may play more 
important roles in the prevention of pigment degradation in Excoecaria (Fig. 3E).

Studies have shown that PODs and laccases (LACs) are responsible for anthocyanin degradation in planta $[35,36]$. In this paper, by using the partially purified anthocyanins from Excoecaria and Osmanthus young leaves respectively, strong $\mathrm{H}_{2} \mathrm{O}_{2}$ dependent ADE activities were detected for Osmanthus leaves but only trace activities for Excoecaria leaves (Fig. 4A-B, D-E). Interestingly, the size of $\mathrm{ADE}$ activity bands detected by in-gel assay (Fig. 4D and E) was of the similar size of the bands shown in the POD activity assay in gel (Fig. 4F), which confirmed that PODs played a major role in anthocyanin degradation in leaves $[36,59]$. A POD antibody was used to prove that the ADE/POD protein levels in the leaves of the two species were not significantly different (Fig. 4J); However, the ADE/POD activities in Excoecaria were dramatically lower than the activities in Osmanthus (Fig. 4C and $\mathrm{F}$ ), indicating inhibitors for ADE/PODs might exist in Excoecaria leaves.

Therefore, we isolated 15 fractions of phenolic components from Excoecaria leaves (Fig. 5A) and found that 4 of the fractions possessed high inhibitory effect on the ADE/ POD activity (Fig. 5B and C). The results of UPLC-MS/ MS further showed that the major components from the 4 fractions (F1, F2, F13, F14) were derivatives of gallic acid (GA), mostly were GGs/ETs (Table 2). The fractions enriched with GGs/ETs were found to inhibit the activity of $\mathrm{ADE} / \mathrm{POD}$ with half maximal inhibitory concentration (IC50) estimated from 67.24 to $83.27 \mu \mathrm{M}$ GAE, which was of slightly less inhibitory effect than GA (IC50 = $35.55 \mu \mathrm{M}$ ) (Fig. 5C). The results indicate that the naturally existed GA and GGs/ETs in Excoecaria leaves inhibit the POD mediated anthocyanin degradation. Inhibition of GA and its derivatives on POD was reported in a previous study, where gallic acid and ellagic acid acted as noncompetitive inhibitors with Ki values as 28.29 and $14.74 \mu \mathrm{M}$ respectively to a bovine lacto-POD [60]. Ellagitannins have been reported to be effective inhibitors for many other enzymes, probably due to their ability to bind proteins [61]. Pomegranate ellagitannins, punicalagin, punicalin, and ellagic acid were identified as $\alpha$-glucosidase inhibitors (IC50 of $140.2,191.4$, and $380.9 \mu \mathrm{M}$, respectively) [62]. Seven ellagitannins were isolated from rose bud extract powder and showed their inhibitory activities on dipeptidyl peptidase-IV (DPP-IV) in the same range as the ellagitannin fractions in the present study [63] (Fig. 5C). An ellagitannin from Agrimonia pilosa Ledeb showed significant inhibitory effect with an IC50 value of $17.03 \pm 0.09 \mu \mathrm{M}$ on protein tyrosine phosphatase [64]. In the present study, except for gallic acid and ellagic acid, multiple GGs/ETs were detected in Excoecaria leaves while neither gallic acid nor its derivatives were found in Osmanthus leaves (Fig. 6) . The data are in agreement with the results that, although similar protein levels of POD were found between Excoecaria and Osmanthus (Fig. 4J), markedly lower activities were detected for the Excoecaria leaves (Fig. 4C). Furthermore, histochemical analysis showed extremely low POD activity was detected in abaxial surfaces of Excoecaria leaves, where hydrolysable tannins located (Fig. 7G-J), which further confirmed that the gallic acid derivatives and ellagitannins inhibited the activity of peroxidases mediating anthocyanin degradation in Excoecaria leaves (Fig. 5).

The stability of anthocyanins also depends on the presence of complexing agents (phenols, metalions) and $\mathrm{pH}$ [65]. Many studies have shown that copigmentation was an effective way to improve the color intensity and stability of anthocyanins [66-69]. Gallic acid is a wellknown copigmentation agent effecting anthocyanin stability in cranberry juice [70], attributed to the shortest distance of its aromatic ring to the anthocyanin panel [71]. Several galloylglucoses and an ellagitannin were identified in the petals of Geranium sylvaticum and efficiently maintained the purple flower color through intermolecular co-pigmentation [72]. In the present study, high levels of simple gallic acid derivatives (galloylglucoses) and ellagitannins were found in Excoecaria leaves, but none was found in Osmanthus (Fig. 6). Gallic acid and the phenolic fractons containing GGs/ETs significantly increased red color intensity of anthocyanin solutions, while the GGs/ETs showed much more significant copigmentation effects than gallic acid (Fig. 7M-O). Furthermore, correlating to previous studies that the gallic acid derivatives caused a more acidic environment than many other organic acids [73, 74], more acid condition was detected for the Excoecaria leaves than Osmanthus, either by the method of $\mathrm{pH}$ value measurement of leaf homogenate (Fig. 8A), or by vacuole neutral red enrichment (Fig. 8B-Q). The fact that hydrolysable tannins and anthocyanins were co-localized on the abaxial side of Excoecaria leaves (Fig. 7A-F); that more acid condition was found for the abaxial surface than the adaxial surface of Excoecaria leaves (Fig. 8), suggested that the existence of gallic acid and its derivatives not only interacted with anthocyanins to increase their stability and color intensification, but also resulted in a low $\mathrm{pH}$ environment in the abaxial side of Excoecaria leaves to maintain red color.

\section{Conclusion}

Taken together, anthocyanins accumulated in abaxial surface of tropical understorey plants provide photoprotection during intermittent exposure to high-intensity sunlight (i.e. sun-patches). Based on the data of the present study, we suggest that a distinct group of phenolics, GGs/ETs, that abundantly accumulated at the abaxially layers of Excoecaria leaves inhibit POD mediated 
anthocyanin degradation and increase stability and color intensity of anthocyanins by copigmentation, leading to the permanent maintenance of the abaxial red leaves.

\section{Materials and methods \\ Plant materials}

Excoecaria cochinchinensis Lour. and Osmanthus fragrans var. semperflorens leaves at three stages (red, greening, green, indicated as stage 1, 2, 3 in Fig. 1A and B) were collected respectively in the campus of South China Agricultural University, Guangzhou City, the South-East of China $\left(23^{\circ} 7^{\prime} \mathrm{N}, 113^{\circ} \mathrm{E}\right)$. The sampled leaves were either subjected to analysis immediately or frozen in liquid $\mathrm{N}_{2}$ and stored under $-80^{\circ} \mathrm{C}$ until use.

\section{Anthocyanin and chlorophyll content determination}

Quantification of anthocyanin was performed as described [75]. The absorbance of the chlorophyll-removed anthocyanin extracts was measured by a spectrophotometer (Shimadzu UV-2450, Kyoto, Japan) at $530 \mathrm{~nm}$ and $645 \mathrm{~nm}$. Anthocyanin content was calculated as $\left(\mathrm{A}_{530}-\right.$ $\left.0.25 \times \mathrm{A}_{645}\right) \mathrm{g}^{-1}$ fresh weight $(\mathrm{FW})$.

To further measure the content of each major anthocyanin during maturation in Excoecaria leaves, the anthocyanin extracts were filtered through $0.22 \mu \mathrm{m}$ hydrophobic polyvinylidene difluoride (PVDF) membrane (ANPEL Scientific Instruments, Shanghai, China) before subjected to HPLC analysis. Separation of the anthocyanins was performed in an Agilent 1200 Series HPLC system (Agilent Tech., Santa Clara, CA, USA). The extracts were injected into a C18(2) column (Luna ${ }^{\oplus}$, $5 \mu \mathrm{m}, 250 \times 4.6 \mathrm{~mm}$, Phenomenex, Torrance, CA, USA). The mobile phase consisted of $0.1 \%$ formic acid (FA) in acetonitrile (A) and 0.1\% FA in water (B). Gradient elution at a flow rate of $0.8 \mathrm{~mL} / \mathrm{min}$ was used from 10 to $45 \%$ A over $35 \mathrm{~min}$ at $35^{\circ} \mathrm{C}$. The injection volume was $20 \mu \mathrm{L}$. The monitoring wavelength was recorded at 530 $\mathrm{nm}$. The relative content of each major anthocyanin (the major peak fractions respectively collected by the HPLC and further identified by the UPLC-QTOF-MS/MS as described in "Anthocyanin profiling") during maturation in Excoecaria leaves was calculated according to the peak area.

For chlorophyll (Chl) content determination, frozen leaves $(1 \mathrm{~g})$ were ground in liquid nitrogen and placed into $10 \mathrm{~mL}$ cold aqueous acetone $(80 \%, \mathrm{v} / \mathrm{v})$ overnight in the dark at $4{ }^{\circ} \mathrm{C}$. After centrifugation at $10,000 \mathrm{~g}$ for 10 min, the residue was re-extracted with the cold aqueous acetone until it became colorless. All the supernatants were combined and brought to $20 \mathrm{~mL}$. Then the absorbance of the Chl supernatant was measured by the spectrophotometer at $663 \mathrm{~nm}$ and $645 \mathrm{~nm}$. The Chl concentration per fresh weight of the leaves was calculated as described [76].

\section{Anthocyanin profiling}

Fifty grams of the red leaves of Excoecaria and Osmanthus were respectively blanched with $350 \mathrm{~mL}$ of $0.3 \mathrm{M} \mathrm{HCl}$ solution by multiple soaking for anthocyanin extraction. Then the crude anthocyanin extracts were partially purified by Amberlite XAD-7 resin (Sigma-Aldrich, Saint Louis, MO, USA) column $(1.5 \times 40 \mathrm{~cm})$ as described [77]. The red fractions were collected and concentrated by a rotary evaporator (Heidolph, Schwabach, Germany). The concentrated anthocyanins were dissolved in $4 \mathrm{~mL}$ of $10 \%(\mathrm{v} / \mathrm{v})$ FA and then loaded onto a column filled with Sephadex LH $20(5.5 \times 90 \mathrm{~cm}$, Sigma) for further purification. Elution was performed with $10 \%$ FA as eluent at a flow rate of $1 \mathrm{~mL} / \mathrm{min}$. Fractions $(2 \mathrm{~mL} /$ tube $)$ were collected with a fraction collector. Elution was monitored by the spectrophotometer at $510 \mathrm{~nm}$. The fractions of the major peak, based on the absorbance values at $510 \mathrm{~nm}$, were pooled and purified again by Amberlite XAD-7 resin to exchange the solvent from $10 \%$ FA to $0.05 \%$ FA in methanol and then concentrated. The purified anthocyanins were filtered through the $0.22 \mu \mathrm{m}$ PVDF membrane and transferred to a vial before analysis.

To identify the purified anthocyanins, high performance liquid chromatography (HPLC) separation coupled with diode array detection (DAD) and electrospray ionization mass spectrometer (ESI/MS) was performed as described [78], in a UPLC1290-6540B Q-TOF (Agilent Tech., Singapore), coupled with a 6540 UHD QTOF ESI Mass spectrometer (Agilent Tech., Singapore). The chromatographic separation was achieved on an Agilent eclipse plus $50 \times 2.1 \mathrm{~mm}, 1.8 \mu \mathrm{m}$ column and the monitoring wavelength was recorded at $280 \mathrm{~nm}$. The mobile phase consisted of acetonitrile (A) and $0.2 \%$ FA in water (B). Gradient elution at a flow rate of $0.4 \mathrm{~mL} /$ min was used from 10 to $90 \% \mathrm{~A}$ at $35^{\circ} \mathrm{C}$. The MS was recorded with a heat capillary voltage of $4 \mathrm{kV}$, spectra were recorded in positive ion mode between $\mathrm{m} / \mathrm{z} 100$ and 1500 with heated dry nitrogen gas at temperature $300{ }^{\circ} \mathrm{C}$ and flow rate $8 \mathrm{~L} / \mathrm{min}$ was used. Nitrogen was used as the nebulizing gas (40 psi) and the fragmentation voltage was $160 \mathrm{~V}$. The identification of the compounds were based on the searching of $\mathrm{m} / \mathrm{z}$ values of the compounds in Metlin databases (https://metlin.scripps.edu/) and comparison of the fragment ions of MS/MS in the databases of Chemspider (http://www.chemspider.com/) and Pubchem (https://pubchem.ncbi.nlm.nih.gov/).

\section{Total tannin content measurement}

The extraction and determination of total tannins were carried out as described [39]. Tannin content was expressed as milligrams of tannic acid (gallotannin, Sigma) equivalents per gram fresh tissue (mg TAE/g FW). 


\section{Anthocyanin location and staining of tannins in the leaf tissue}

Hand cross sections of leaf blades of Excoecaria and Osmanthus were respectively immersed in $\mathrm{ddH}_{2} \mathrm{O}$ and observed for pigment distribution by a light microscopy (Leica Microsystems, Germany).

Staining of tannins in the leaf tissue was performed according to the method as described [79]. Firstly, the fixation and sectioning were carried out as described [39]. Briefly, discs $(2 \mathrm{~mm} \times 2 \mathrm{~mm})$ of Excoecaria and Osmanthus leaves were respectively fixed for $12 \mathrm{~h}$ in $100 \mathrm{mM}$ phosphate buffer (PBS, pH 7.2) containing 4\% $(\mathrm{w} / \mathrm{v})$ paraformaldehyde, $2 \%(\mathrm{w} / \mathrm{v})$ glutaraldehyde. After washed in PBS and dehydrated and infiltrated in gradient ethanol and LRWhite resin (Sigma), respectively, the mixture was finally replaced by pure LRWhite. Samples were then transferred to capsules with fresh LRWhite, and cured under two 15-watt ultraviolet lamps $(360 \mathrm{~nm})$ for at least $24 \mathrm{~h}$ at $-20{ }^{\circ} \mathrm{C}$, and then continued curing for $48 \mathrm{~h}$ at RT [39]. For tannins staining, 5- $\mu \mathrm{m}$-thick sections obtained on a microtome (Leica Microsystems, Wetzlar, Germany) were incubated in ruthenium red ( $0.05 \%$ aqueous) for $2 \mathrm{~min}$ and then washed before incubated again in toluidine blue $(0.1 \%$ aqueous $)$ for $1 \mathrm{~min}$ [79]. Observations and photographs were done on a light microscope (Optiphot, Nikon, Tokyo, Japan). To better understand the levels of hydrolysable tannins out of the above tannins staining in the leaves, vanillin staining of condensed tannins (PAs) in plant tissues was also performed as described [39].

\section{Non-targeted phenolic compound analysis by UPLC-DAD- QTOF-MS/MS}

Phenolics were extracted as described [80], using 70\% $(\mathrm{v} / \mathrm{v})$ of aqueous acetone containing $1 \%(\mathrm{w} / \mathrm{v})$ benzothiadiazole $(\mathrm{BTH})$ as extraction solution. The final extracts $(100 \mu \mathrm{L})$ were dried under the nitrogen stream, redissolved in $1 \mathrm{~mL} 60 \%(\mathrm{v} / \mathrm{v})$ ethanol, filtered through the $0.22 \mu \mathrm{m}$ PVDF membrane and transferred to a vial before analysis.

Non-target profiles of the above phenolic extracts from the leaves of Excoecaria and Osmanthus were further respectively characterized by UPLC-QTOF-MS/MS as described in "Anthocyanin profiling", while the MS was recorded with a heat capillary voltage of $3.5 \mathrm{kV}$, spectra were recorded in negative ion mode between $\mathrm{m} /$ z 100 and 1100. The fragmentation voltage was $150 \mathrm{~V}$.

\section{Column chromatography of the phenolic compounds with Sephadex LH 20}

The above phenolic extracts from the leaves were also purified by Sephadex LH $20(1.5 \times 70 \mathrm{~cm})$ column chromatography. The dried crude extracts $(1 \mathrm{~g}$ dried sample extraction for described column dimension) were first dissolved in $2 \mathrm{~mL}$ aqueous 3\% (v/v) FA and the insoluble residue was then dissolved in $1 \mathrm{~mL}$ methanol. The $3 \mathrm{~mL}$ sample was loaded onto the column that had been equilibrated with aqueous 3\% (v/v) FA. Elution was performed with gradient aqueous methanol, from 20 to $100 \%$, at a flow rate of $20 \mathrm{~mL} / \mathrm{h}$. Fractions (3 mL/tube) were collected with a fraction collector.

Based on the peaks of absorbance values at $280 \mathrm{~nm}$ (Fig. 5A), the fractions of the phenolic extracts were combined and grouped to 15 big fractions namely F1F15. Total phenolic content of the 15 fractions was determined using Folin-Ciocalteu assay as described [39]. The content was calculated as gallic acid equivalents $(\mu \mathrm{g} / \mathrm{mL}$ GAE) by using gallic acid calibration curve.

\section{Gallic acid content determined by HPLC}

Phenolics in the three stages of Excoecaria and Osmanthus leaves were respectively extracted and prepared as described in "Non-targeted phenolic compound analysis by UPLC-DAD-QTOF-MS/MS" [80]. The filtered extracts of each sample were separated by HPLC as described [39]. The temperature of the column was $25^{\circ} \mathrm{C}$. The peak of the gallic acid (GA) in each sample was identified by comparison with the retention time of standard gallic acid (Sigma-Aldrich), and was further confirmed by a standard addition method. Briefly, 2, $4 \mu \mathrm{g} / \mathrm{mL}$ standard gallic acid was added respectively in the sample extracts and the increase in the peak area of gallic acid was monitored. The gallic acid content $[\mathrm{mg} / \mathrm{g} \mathrm{DW}$ (dry weight)] in the crude extracts of each sample was calculated according to the gallic acid standard curve.

Enzyme extraction, SDS-PAGE and POD immunodetection Crude enzyme was extracted by homogenizing the leaves (2 g) with $8 \mathrm{~mL}$ of $0.1 \mathrm{M} \mathrm{pH} 7.0$ potassium phosphate buffer (KPB), containing 30\% (w/w) Polyvinylpolypyrrolidone (PVPP) and $80 \mu \mathrm{L}$ of protease inhibitor solution [1 tablet of protease inhibitor (cOmplete ${ }^{\mathrm{TM}}$, Mini, Ethylenediaminetetraacetic acid (EDTA)-free Protease Inhibitor Cocktail, Roche, Mannheim, Germany) was dissolved in $10 \mathrm{ml} \mathrm{KPB}$. After centrifugation $\left(20 \mathrm{~min}, 12,000 \mathrm{~g}, 4^{\circ} \mathrm{C}\right.$ ), the supernatants were collected as crude enzyme extract or soluble fraction of the protein extract [81]. The residue from the above extraction was resuspended and homogenized in the above KPB containing $8 \mathrm{M}$ urea. After centrifugation, the supernatants were collected as insoluble fraction of the protein extract [39]. Protein concentration was determined using Coomassie Brilliant Blue G-250.

Crude enzyme extract was denatured in Laemmli's sample buffer by $10 \mathrm{~min}$ of boiling prior to separation in $10 \%(\mathrm{w} / \mathrm{v})$ sodium dodecyl sulfate-polyacrylamide gel 
electrophoresis (SDS-PAGE) according to standard conditions [39].

Immunodetection for POD level in the leaves was performed as described [39], using the polyclonal antiHorseradish POD antibody (Agrisera Antibody, Vännäs, Sweden).

\section{Anthocyanin degradation enzyme/peroxidase (ADE/POD) activity assay}

Anthocyanins in Excoecaria and Osmanthus leaves were respectively extracted and partially purified as described in "Anthocyanin profiling". The concentration of anthocyanins was determined using the pH-differential method as described [82]. Two anthocyanin substrates for ADE/POD activity assay were prepared respectively diluting the concentrated anthocyanins using $0.2 \mathrm{M}$ sodium acetate buffer ( $\mathrm{pH} 4.0)$ to final concentration 0.05 M.

For ADE/POD activity using the anthocyanin substrates, crude enzyme extracts $(0.1 \mathrm{~mL})$ were added to $2.0 \mathrm{~mL}$ of the above anthocyanin substrates with or without $2 \mathrm{mM} \mathrm{H}_{2} \mathrm{O}_{2}$. The mixture was incubated for $20 \mathrm{~min}$ at $40{ }^{\circ} \mathrm{C}$. The reaction was terminated by adding $2 \mathrm{~mL}$ of $0.1 \mathrm{M} \mathrm{HCl}$ in methanol. The decrease in absorbance due to degradation of anthocyanins in the reaction mixture was recorded at $530 \mathrm{~nm}$, compared to the reaction set up in parallel with denatured enzyme. As described [40], one unit of ADE activity was defined as the amount of ADEs needed for degradation of $1 \mu \mathrm{mol}$ of cyanidin-3glucoside $\left(\varepsilon=29,600 \mathrm{M}^{-1} \mathrm{~cm}^{-1}\right)$ per hour at $40{ }^{\circ} \mathrm{C}$. ADE activity was expressed as $\mu \mathrm{mol} \mathrm{h} \mathrm{h}^{-1} \mathrm{~g}^{-1} \mathrm{FW}$.

For POD activity using the guaiacol substrate, the activity was measured using guaiacol as a substrate in a reaction mixture $(3 \mathrm{~mL})$, containing $0.05 \mathrm{~mL}$ crude enzyme extract, $2.75 \mathrm{~mL} 50 \mathrm{mM}$ phosphate buffer (pH 7.0), $100 \mu \mathrm{L}$ of $150 \mathrm{mM} \mathrm{H}_{2} \mathrm{O}_{2}$ and $200 \mu \mathrm{L}$ of $200 \mathrm{mM}$ guaiacol. As described [83], the increase in absorbance due to oxidation of guaiacol in the reaction mixture was monitored at $470 \mathrm{~nm}\left(\varepsilon=6740 \mathrm{M}^{-1} \mathrm{~cm}^{-1}\right)$ for $2 \mathrm{~min}$ by the spectrophotometer. POD activity was expressed as $\mu \mathrm{mol} / \mathrm{h}^{-1} \mathrm{~g}^{-1} \mathrm{FW}\left(1 \mu \mathrm{mol}\right.$ of substrate conversion $/ \mathrm{h}^{-1}$ $\left.\mathrm{g}^{-1} \mathrm{FW}\right)$.

ADE/POD activity gel staining using the two substrates with or without $\mathrm{H}_{2} \mathrm{O}_{2}$ was carried out after PAGE as described above but without protein sample boiling namely semi-native PAGE. The gel was then rinsed twice with the buffer for $5 \mathrm{~min}$ to remove SDS and immersed in the same buffer containing the substrates with $2 \mathrm{mM}$ $\mathrm{H}_{2} \mathrm{O}_{2}$ or without $\mathrm{H}_{2} \mathrm{O}_{2}$ until the bands were visualized.

\section{Partial purification of peroxidase from Osmanthus leaves}

Eighty grams of frozen Osmanthus leaves were ground and immediately homogenized in $300 \mathrm{~mL}$ of $0.1 \mathrm{M} \mathrm{KPB}$ (pH 7.0), containing 8.6 mM Dithiothreitol (DTT), $5 \mathrm{mM}$
EDTA, $1 \mathrm{mM}$ phenylmethylsulfonyl fluoride (PMSF) and $5 \%(\mathrm{w} / \mathrm{v})$ PVPP, followed by centrifugation at $12,000 \mathrm{~g}$ for $20 \mathrm{~min}$ [39]. The extract was fractionated further by precipitation with ammonium sulfate at 70 to $100 \%$ saturation and centrifugation at $12,000 \mathrm{~g}$ for $20 \mathrm{~min}$. The precipitate was re-suspended again and dialyzed against $0.01 \mathrm{M} \mathrm{KPB} \mathrm{(pH} \mathrm{7.0)} \mathrm{containing} \mathrm{2.2} \mathrm{mM} \mathrm{DTT.}$

\section{The stabilities of anthocyanins in vitro}

The three major anthocyanins purified and identified in "Anthocyanin profiling" and shown in Fig. 2 were freezedried and re-dissolved in $0.2 \mathrm{M}$ sodium acetate buffer ( $\mathrm{pH}$ 4.0). ADE/POD activity assay was carried out as described below, the purified Osmanthus POD $(5 \mu \mathrm{L})$ were added to $125 \mu \mathrm{L}$ of the above prepared substrates with $1 \mu \mathrm{L}$ of $1 \mathrm{mM} \mathrm{H}_{2} \mathrm{O}_{2}$. The mixture was incubated for 20 min at $25^{\circ} \mathrm{C}$. The reaction was terminated by adding $125 \mu \mathrm{L}$ chloroform. After centrifugation $(13,000 \mathrm{~g}, 5$ $\mathrm{min}$ ), relative content of the remained anthocyanins in the supernatant was determined by HPLC at $510 \mathrm{~nm}$ as described in "Anthocyanin and chlorophyll content determination", compared to the reaction set up in parallel with denatured enzyme.

The anthocyanins $(0.05 \mathrm{mM})$ were prepared respectively in $0.4 \mathrm{M}$ citric acid-disodium hydrogen phosphate buffer at $\mathrm{pH} 3.0$ and placed at room temperature for 21 days. The absorbance at $510 \mathrm{~nm}$ of each anthocyanin solution was recorded at 0 day and 21 days respectively to analyze the stabilities of the different types of anthocyanins.

\section{Determination of IC50 values and copigmentation effect for the tannin constituents}

The half maximal inhibitory concentration (IC50) of the tannin constituents on the purified Osmanthus POD $(0.6 \mu \mathrm{g})$ was tested by $0,10,20,40,60,80,100 \mu \mathrm{M}$ GAE of the F1, F2, F13, F14 sub-fractions and GA. The POD activities were measured as described above and the inhibition ratio was obtained by calculating the percentage of the decrease in the activity due to the addition of the tannin constituents, to the activity without addition.

The F1, F1, F2, F13 and F14 four fractions of 0, 100, $300 \mu \mathrm{g} / \mathrm{mL}$ GAE were added to the anthocyanin solutions respectively, with same level of gallic acid as a reference. The absorbance at $510 \mathrm{~nm}$ of each mixture was recorded $2 \mathrm{~h}$ after addition to analyze the effect of tannin constituents on color intensities of anthocyanins.

\section{Histochemical staining and localization of ADE/POD in the leaf tissue}

Leaf blade cross sections were hand cut using a razor blade, rinsed in cold PBS (phosphate buffer) $(50 \mathrm{mM}$, $\mathrm{pH}$ 7.0), and incubated for $20 \mathrm{~min}$ at $25^{\circ} \mathrm{C}$ with catalase (100 mg/mL; Sigma-Aldrich) to eliminate endogenous 
hydrogen peroxide. Samples were then rinsed several times to remove the catalase and incubated at $25^{\circ} \mathrm{C}$ in the PBS containing $13.3 \mathrm{mM}$ guaiacol and $5 \mathrm{mM} \mathrm{H}_{2} \mathrm{O}_{2}$. The controls were cross sections boiled for $15 \mathrm{~min}$ to destroy enzyme activity. The treated cross sections were observed by the light microscopy [35].

\section{Tissue cell sap $\mathrm{pH}$ and vacuolar acidity detection by neutral red staining}

The leaf tissue cell sap $\mathrm{pH}$ was determined as described [84]. The $\mathrm{pH}$ of the homogenate was measured by a $\mathrm{pH}$ meter (Satorious, Göttingen, Germany). Neutral red (NR, Sigma) was used to detect the subvacuolar acidity of the leaf cells [85]. Fresh leaf tissue slices of Excoecaria and Osmanthus were respectively immersed in NR solution $(20 \mathrm{mg} / \mathrm{L})$ and incubated for $20 \mathrm{~min}$ at room temperature. The adaxial/abaxial epidermal cells of NRstained and non-stained tissue slices were observed by the light microscopy.

\section{Statistical analysis}

Data were collected from three biological replicate samples. Values were presented as means \pm standard error of mean (SEM). Means were compared by unpaired $t$ test $(P<0.05)$ using the GraphPad QuickCalcs online software (Prism 7, GraphPad Software, San Diego, CA, USA).

\section{Additional files}

Additional file 1: Figure S1. HPLC profiles of the anthocyanins in Excoecaria leaves and identification by UPLC-DAD-QTOF-MS/MS. (A-C) Anthocyanin contents in Excoecaria leaves during maturation. Anthocyanin contents in Excoecaria leaves from stage 1 to 3 (as indicated in Fig. 1A) were analyzed by HPLC (A510nm). (D) Peak 1 (P1) identified by UPLCDAD-QTOF-MS/MS. P1 as indicated in (A-C) was further identified to be Cy-3-O glucoside. (E) Peak 2 (P2) identified by UPLC-DAD-QTOF-MS/MS P2 as indicated in (A-C) was further identified to be cyanidin 3-(2"-galloylglucoside). (TIF $10184 \mathrm{~kb})$

Additional file 2: Figure S2. Identification of the Major POD inhibitors from Excoecaria leaves by UPLC-DAD-QTOF-MS/MS. (A-D) Characterization of the compounds in the high inhibition fractions by UPLC-DAD-QTOFMS/MS. The MS and MS/MS spectra of the major compounds with high absorbance at $280 \mathrm{~nm}$ indicate various hydrolysable tannins in the high inhibition fractions of F1 (A), F2 (B), F13(C) and F14 (D) as described in Fig. 5A and B. (TIF $10206 \mathrm{~kb}$ )

Additional file 3: Figure S3. Gallic acid content determination by HPLC using internal standard method. (A, E) HPLC analysis of standard gallic acid. (B, F) HPLC analysis of gallic acid in the phenolic extracts of the leaves at stage 2 of Excoecaria (B) and Osmanthus (F). (C-D) HPLC analysis of gallic acid in the phenolic extracts of the leaves at stage 2 of Excoecaria, with $2 \mu \mathrm{g} / \mathrm{mL}$ (C) and $4 \mu \mathrm{g} / \mathrm{mL}$ (D) standard gallic acid addition in the extracts. (G-H) HPLC analysis of gallic acid in the tannin extracts of the leaves at stage 2 of Osmanthus, with $2 \mu \mathrm{g} / \mathrm{mL}$ (G) and $4 \mu \mathrm{g} / \mathrm{mL}(\mathrm{H})$ standard gallic acid addition in the extracts. (TIF $9908 \mathrm{~kb}$ )

Additional file 4: Data file 1. MSMS compound report of Excoecaria phenolics used in this study. (PDF $21926 \mathrm{~kb}$ )

Additional file 5: Data file 2. MSMS compound report of Osmanthus phenolics used in this study. (PDF $6486 \mathrm{~kb}$ )

\section{Abbreviations}

$[\mathrm{M}+\mathrm{H}]^{+}$: Molecular ion; $[\mathrm{M}-\mathrm{H}]^{-}$: Molecular ion; ADE: Anthocyanin degradation enzyme; BTH: Benzothiadiazole; Cpd: Compound; DAD: Diode array detection; DPP: Dipeptidyl peptidase; DTT: Dithiothreitol; DW: Dry weight; EDTA: Ethylenediaminetetraacetic acid; ESI/MS: Electrospray ionization mass spectrometer; FA: Formic acid; GA: Gallic acid; GAE: Gallic acid equivalents; GGs/ETs: Galloylglucoses/ellagitannins; HHDP: Hexahydroxydiphenoyl; HPLC: High performance liquid chromatography; IC50: The half maximal inhibitory concentration; KPB: Potassium phosphate buffer; LAC: Laccase; NPQ: Non-photochemical quenching; NR: Neutral red; P: Peak; PAs: Proanthocyanidins/Condensed tannins; PBS: Phosphate buffer; PMSF: Phenylmethylsulfonyl fluoride; POD: Peroxidase; PPOs: Polyphenol oxidases; PVDF: polyvinylidene difluoride; PVPP: Polyvinylpolypyrrolidone; Rt: Retention time; SDS-PAGE: Sodium dodecyl sulfate-polyacrylamide gel electrophoresis; SEM: Standard error of mean; TAE: Tannic acid equivalents; UPLC-QTOF-MS/MS: Ultra-performance liquid chromatography quadrupole time of flight mass spectrometry; VAZ/Chl: Total xanthophyll to chlorophyll

\section{Acknowledgements}

The authors thank Mr. Chong Yang (Instrumenttal Analysis \& Research Center, South China Agricultural University) for helping to do the UPLC-DADQTOF-MS/MS analysis.

\section{Authors' contributions}

$H L, W L$ and $X Z$ collected samples and performed most of the experiments. HL processed the tables and Figs. SD, QX and TH helped in performing physiological and chemical experiments. XP contributed to the UPLC-DADQTOF-MS/MS data analysis and wrote part of the article. ZZ and XZ conceived the project, analyzed the data, wrote and revised the article. All authors read and approved the final version of the manuscript.

\section{Funding}

This work was supported by the National Natural Science Foundation of China (31171988 and 31772036), and the National Key Basic Research Program of China (2013CB127105). The funding agencies provided the experimental costs, graduate student salary support and publication fees for this work.

Availability of data and materials

All data generated or analyzed in this study are included in this published article and its additional files.

Ethics approval and consent to participate

Not applicable.

\section{Consent for publication}

Not applicable.

\section{Competing interests}

The authors declare that they have no competing interests.

\section{Author details}

${ }^{1}$ State Key Laboratory for Conservation and Utilization of Subtropical Agro-bioresources/ Guangdong Provincial Key Laboratory of Postharvest Science of Fruits and Vegetables/ College of Horticulture, South China Agricultural University, Guangzhou 510642, China. ${ }^{2}$ College of Life Sciences, South China Agricultural University, Guangzhou 510642, China.

Received: 19 December 2018 Accepted: 25 June 2019

Published online: 15 July 2019

\section{References}

1. Steyn W, Wand S, Holcroft D, Jacobs G. Anthocyanins in vegetative tissues: a proposed unified function in photoprotection. New Phytol. 2002;155(3):349-61.

2. Grotewold E. The genetics and biochemistry of floral pigments. Annu Rev Plant Biol. 2006:57:761-80.

3. Gould K, Jay-Allemand C, Logan BA, Baissac Y, Bidel L. When are foliar anthocyanins useful to plants? Re-evaluation of the photoprotection hypothesis using Arabidopsis thaliana mutants that differ in anthocyanin accumulation. Environ Exp Bot. 2018;154:11-22. 
4. Cooney LJ, Logan BA, Walsh MJ, Nnatubeugo NB, Reblin JS, Gould KS. Reprint of "Photoprotection from anthocyanins and thermal energy dissipation in senescing red and green Sambucus canadensis peduncles". Environ Exp Bot. 2018;154:4-10.

5. Chalker-Scott L. Environmental significance of anthocyanins in plant stress responses. Photochem Photobiol. 1999;70(1):1-9.

6. Oren-Shamir M. Does anthocyanin degradation play a significant role in determining pigment concentration in plants? Plant Sci. 2009;177(4):310-6.

7. Bertamini M, Nedunchezhian N. Photoinhibition of photosynthesis in mature and young leaves of grapevine (Vitis vinifera L.). Plant Sci. 2003; 164(4):635-44.

8. Malnoë A. Photoinhibition or photoprotection of photosynthesis? Update on the (newly termed) sustained quenching component qH. Environ Exp Bot. 2018;154:123-33.

9. Winkel-Shirley B. Biosynthesis of flavonoids and effects of stress. Curr Opin Plant Biol. 2002:5(3):218-23.

10. Manetas Y, Drinia A, Petropoulou Y. High contents of anthocyanins in young leaves are correlated with low pools of xanthophyll cycle components and low risk of photoinhibition. Photosynthetica. 2002; 40(3):349-54.

11. Hughes NM, Burkey KO, Cavender-Bares J, Smith WK. Xanthophyll cycle pigment and antioxidant profiles of winter-red (anthocyanic) and winter-green (acyanic) angiosperm evergreen species. J Exp Bot. 2011; 63(5):1895-905

12. Tattini M, Landi M, Brunetti C, Giordano C, Remorini D, Gould KS, Guidi L. Epidermal coumaroyl anthocyanins protect sweet basil against excess light stress: multiple consequences of light attenuation. Physiol plantarum. 2014; 152(3):585-98

13. Tattini M, Sebastiani F, Brunetti C, Fini A, Torre S, Gori A, Centritto M, Ferrini F, Landi M, Guidi L. Dissecting molecular and physiological response mechanisms to high solar radiation in cyanic and acyanic leaves: a case study on red and green basil. J Exp Bot. 2017;68(9):2425-37.

14. Lo Piccolo E, Landi M, Pellegrini E, Agati G, Giordano C, Giordani T, Lorenzini G, Malorgio F, Massai R, Nali C, Rallo G, Remorini D, Vernieri P, Guidi L. Multiple consequences induced by epidermally-located anthocyanins in young, mature and senescent leaves of Prunus. Front Plant Sci. 2018:9:917.

15. Sytar O, Zivcak M, Bruckova K, Brestic M, Hemmerich I, Rauh C, Simko I. Shift in accumulation of flavonoids and phenolic acids in lettuce attributable to changes in ultraviolet radiation and temperature. Sci Hortic. 2018;239:193-204.

16. Hatier JHB, Gould KS. Anthocyanin function in vegetative organs. In: Davies K, Gould KS, editors. Anthocyanins. New York: Springer; 2008. p. 1-19.

17. Close DC, Beadle CL. The ecophysiology of foliar anthocyanin. Bot Rev. 2003;69(2):149-61.

18. Oren-Shamir M, Nissim-Levi A. Temperature and gibberellin effects on growth and anthocyanin pigmentation in Photinia leaves. J Hortic Sci Biotechnol. 1999;74(3):355-60.

19. Nissim-Levi A, Kagan S, Ovadia R, Oren-Shami M. Effects of temperature, UVlight and magnesium on anthocyanin pigmentation in cocoplum leaves. J Hortic Sci Biotechnol. 2003;78(1):61-4.

20. Lee DW, Collins TM. Phylogenetic and ontogenetic influences on the distribution of anthocyanins and betacyanins in leaves of tropical plants. Int J Plant Sci. 2001;162(5):1141-53.

21. Lee DW, Lowry JB, Stone B. Abaxial anthocyanin layer in leaves of tropical rain forest plants: enhancer of light capture in deep shade. Biotropica. 1979; 11(1):70-7.

22. Klančnik K, Levpušček M, Gaberščik A. Variegation and red abaxial epidermis define the leaf optical properties of Cyclamen purpurascens. Flora. 2016;224:87-95.

23. Wang Y, Shao L, Wang J, Ren H, Liu H, Zhang Q, Guo Q, Chen X. Comparison of morphological and physiological characteristics in two phenotypes of a rare and endangered plant, Begonia fimbristipula Hance. Photosynthetica. 2016;54(3):381-9.

24. Hughes NM, Vogelmann TC, Smith WK. Optical effects of abaxial anthocyanin on absorption of red wavelengths by understorey species: revisiting the back-scatter hypothesis. J Exp Bot. 2008;59(12):3435-42.

25. Hughes NM, Carpenter KL, Keidel TS, Miller CN, Waters MN, Smith WK. Photosynthetic costs and benefits of abaxial versus adaxial anthocyanins in Colocasia esculenta 'mojito'. Planta. 2014;240(5):971-81.

26. Manetas Y. Why some leaves are anthocyanic and why most anthocyanic leaves are red? Flora-morphology, distribution. Functional Ecology of Plants. 2006;201(3):163-77.
27. Fernández-Marín B, Esteban R, Míguez F, Artetxe U, Castañeda V, PintóMarijuan M, Becerril JM, García-Plazaola Jl. Ecophysiological roles of abaxia anthocyanins in a perennial understorey herb from temperate deciduous forests. AoB Plants. 2015;7.

28. Tanaka Y, Sasaki N, Ohmiya A. Biosynthesis of plant pigments: anthocyanins, betalains and carotenoids. Plant J. 2008:54(4):733-49.

29. Petroni $K$, Tonelli $C$. Recent advances on the regulation of anthocyanin synthesis in reproductive organs. Plant Sci. 2011;181(3):219-29.

30. Passeri V, Koes R, Quattrocchio FM. New challenges for the design of high value plant products: stabilization of anthocyanins in plant vacuoles. Front Plant Sci. 2016;7:153.

31. Liu Y, Tikunov Y, Schouten RE, Marcelis LF, Visser RG, Bovy A. Anthocyanin biosynthesis and degradation mechanisms in Solanaceous vegetables: a review. Front Chem. 2018;6:52.

32. Taranto F, Pasqualone A, Mangini G, Tripodi P, Miazzi MM, Pavan S, Montemurro C. Polyphenol oxidases in crops: biochemical, physiological and genetic aspects. Int J Mol Sci. 2017;18(2):377.

33. Kader F, Haluk JP, Nicolas JP, Metche M. Degradation of cyanidin 3glucoside by blueberry polyphenol oxidase: kinetic studies and mechanisms. J Agr Food Chem. 1998;46(8):3060-5.

34. Pang $X$, Huang $X$, Yang $X$, Ji Z, Zhang Z. Role of polyphenol oxidase in anthocyanin degradation of lychee pericarp. Sci Agric Sinica. 2008;41:540-5.

35. Fang F, Zhang X, Luo H, Zhou J, Gong Y, Li W, Shi Z, He Q, Wu Q, Li L, Jiang $L$, Cai Z, Oren-Shamir M, Zhang Z, Pang X. An intracellular laccase is responsible for epicatechin-mediated anthocyanin degradation in litchi fruit pericarp. Plant Physiol. 2015;169(4):2391-408.

36. Zipor G, Duarte P, Carqueijeiro I, Shahar L, Ovadia R, Teper-Bamnolker $P$, Eshel D, Levin Y, Doron-Faigenboim A, Sottomayor M, Oren-Shamir M. In planta anthocyanin degradation by a vacuolar class III peroxidase in Brunfelsia calycina flowers. New Phytol. 2015;205(2):653-65.

37. Lachman J, Hamouz K. Red and purple coloured potatoes as a significant antioxidant source in human nutrition-a review. Plant Soi Environ. 2005;51(11):477

38. Woodward G, Kroon P, Cassidy A, Kay C. Anthocyanin stability and recovery: implications for the analysis of clinical and experimental samples. J Agr Food Chem. 2009:57(12):5271-8.

39. Luo H, Deng S, Fu W, Zhang X, Zhang X, Zhang Z, Pang X. Characterization of active anthocyanin degradation in the petals of rosa chinensis and brunfelsia calycina reveals the effect of gallated catechins on pigment maintenance. Int J Mol Sci. 2017;18(4):699.

40. Zhang Z, Pang $X$, Ji Z, Jiang $Y$. Role of anthocyanin degradation in litchi pericarp browning. Food Chem. 2001;75(2):217-21.

41. Mazza G, Minitiati E. Anthocyanin in fruits, vegetables, and grains. Boca Raton: CRC press; 1993.

42. Schmitzer V, Veberic R, Osterc G, Stampar F. Color and phenolic content changes during flower development in groundcover rose. J Am Soc Hortic Sci. 2010:135(3):195-202.

43. Kondo T, Ueda M, Isobe M, Goto T. A new molecular mechanism of blue color development with protocyanin, a supramolecular pigment from cornflower, Centaurea cyanus. Tetrahedron Lett. 1998;39(45):8307-10.

44. Mazza G, Brouillard R. The mechanism of co-pigmentation of anthocyanins in aqueous solutions. Phytochemistry. 1990;29(4):1097-102.

45. Zhang Y, Butelli E, Martin C. Engineering anthocyanin biosynthesis in plants. Curr Opin Plant Biol. 2014;19:81-90.

46. Anjaneyulu ASR, Rao VL. Five diterpenoids (agallochins A-E) from the mangrove plant Excoecaria agallocha Linn. Phytochemistry. 2000;55(8): 891-901.

47. Giang PM, Son PT, Matsunami K, Otsuka H. New Megastigmane glucosides from Excoecaria cochinchinensis LOUR. Var. cochinchinensis. Chem Pharm Bull. 2005;53(12):1600-3.

48. Huxely A. New RHS Dictionary of Gardening, Lawns. London: Macmillan. ISBN 0-333-47494-5: 1992

49. Riffault $L$, Destandau E, Pasquier L, André P, Elfakir C. Phytochemical analysis of Rosa hybrida cv.'Jardin de Granville'by HPTLC, HPLC-DAD and HPLC-ESIHRMS: polyphenolic fingerprints of six plant organs. Phytochemistry. 2014; 99:127-34.

50. Liberal J, Costa G, Carmo A, Vitorino R, Marques C, Domingues MR, Domingues $P$, Goncalves $A C$, Alves R, Sarmento-Ribeiro AB, Girão $H$, Cruz MT, Batista MT. Chemical characterization and cytotoxic potential of an ellagitannin-enriched fraction from Fragaria vesca leaves. Arab J Chem. 2015. http://dx.doi.org/10.1016/j.arabjc.2015.11.014. 
51. Bercu R. Histoanatomical study on the vegetative organs of Tradescantia spathacea (Commelinaceae). Botanica Serbica. 2013;37(2):121-6.

52. Lee DW, Graham R. Leaf optical properties of rainforest sun and extreme shade plants. Am J Bot. 1986;73(8):1100-8

53. Fossen T, Andersen ØM. Cyanidin 3-(2", 3"-digalloylglucoside) from red leaves of Acer platanoides. Phytochemistry. 1999;52(8):1697-700.

54. Reiersen B, Kiremire BT, Byamukama R, Andersen ØM. Anthocyanins acylated with gallic acid from chenille plant, Acalypha hispida. Phytochemistry. 2003;64(4):867-71.

55. Giusti MM, Wrolstad RE. Acylated anthocyanins from edible sources and their applications in food systems. Biochem Eng J. 2003;14(3):217-25.

56. Kammerer D, Carle R, Schieber A. Quantification of anthocyanins in black carrot extracts (Daucus carota ssp. sativus var. atrorubens Alef.) and evaluation of their color properties. Eur Food Res Technol. 2004;219(5):479-86.

57. Sadilova E, Stintzing F, Carle R. Thermal degradation of acylated and nonacylated anthocyanins. J Food Sci. 2006;71(8):C504-12.

58. Ferreira da Silva P, Paulo L, Barbafina A, Elisei F, Quina FH, Maçanita AL. Photoprotection and the photophysics of acylated anthocyanins. Chem-Eur J. 2012;18(12):3736-44

59. Zhang Z, Pang $X$, Duan $X$, Ji Z, Jiang $Y$. Role of peroxidase in anthocyanin degradation in litchi fruit pericarp. Food Chem. 2005;90(1):47-52.

60. Sarikaya SBO, Sisecioglu M, Cankaya M, Gulcin I, Ozdemir H. Inhibition profile of a series of phenolic acids on bovine lactoperoxidase enzyme. J Enzym Inhib Med Chem. 2015;30(3):479-83.

61. Wang $Y$, Zhang $H$, Liang H, Yuan Q. Purification, antioxidant activity and protein-precipitating capacity of punicalin from pomegranate husk. Food Chem. 2013;138(1):437-43.

62. Bellesia A, Verzelloni E, Tagliazucchi D. Pomegranate ellagitannins inhibit aglucosidase activity in vitro and reduce starch digestibility under simulated gastro-intestinal conditions. Int J Food Sci Nutr. 2015;66(1):85-92.

63. Kato $E$, Uenishi $Y$, Inagaki $Y$, Kurokawa $M$, Kawabata J. Isolation of rugosin a, $B$ and related compounds as dipeptidyl peptidase-IV inhibitors from rose bud extract powder. Biosci Biotechnol Biochem. 2016;80(11):2087-92.

64. Nguyen DH, Seo UM, Zhao BT, Le DD, Seong SH, Choi JS, Min BS, Woo MH. Ellagitannin and flavonoid constituents from Agrimonia pilosa Ledeb. With their protein tyrosine phosphatase and acetylcholinesterase inhibitory activities. Bioorg Chem. 2017;72:293-300.

65. Markakis P. Stability of anthocyanins in foods. In: Markakis P, editor. Anthocyanins as food colors. New York: Academic Press; 1982. p. 163-78.

66. Gómez-Míguez M, González-Manzano S, Escribano-Bailón MT, Heredia FJ, Santos-Buelga C. Influence of different phenolic copigments on the color of malvidin 3-glucoside. J Agric Food Chem. 2006;54(15):5422-9.

67. Cavalcanti RN, Santos DT, Meireles MAA. Non-thermal stabilization mechanisms of anthocyanins in model and food systems-an overview. Food Res Int. 2011;44(2):499-509.

68. Heras-Roger J, Alonso-Alonso O, Gallo-Montesdeoca A, Díaz-Romero C, Darias-Martín J. Influence of copigmentation and phenolic composition on wine color. J Food Sci Tech. 2016;53(6):2540-7.

69. Weber F, Boch K, Schieber A. Influence of copigmentation on the stability of spray dried anthocyanins from blackberry. LWT-Food Sci Technol. 2017;75:72-7

70. Roidoung S, Dolan KD, Siddiq M. Gallic acid as a protective antioxidant against anthocyanin degradation and color loss in vitamin-C fortified cranberry juice. Food Chem. 2016;210:422-7.

71. Qian BJ, Liu JH, Zhao SJ, Cai JX, Jing P. The effects of gallic/ferulic/caffeic acids on colour intensification and anthocyanin stability. Food Chem. 2017; 228:526-32.

72. Tuominen A, Sinkkonen J, Karonen M, Salminen JP. Sylvatiins, acetylglucosylated hydrolysable tannins from the petals of Geranium sylvaticum show co-pigment effect. Phytochemistry. 2015;115:239-51.

73. Peleg $\mathrm{H}$, Bodine KK, Noble AC. The influence of acid on astringency of alum and phenolic compounds. Chem Senses. 1998;23(3):371-8.

74. Mota FL, Queimada AJ, Pinho SP, Macedo EA. Aqueous solubility of some natural phenolic compounds. Ind Eng Chem Res. 2008:47(15):5182-9.

75. Zhu Q, Sui S, Lei X, Yang Z, Lu K, Liu G, Liu YG, Li M. Ectopic expression of the coleus R2R3 MYB-type proanthocyanidin regulator gene SsMYB3 alters the flower color in transgenic tobacco. PLoS One. 2015;10(10):e0139392.

76. Arnon DI. Copper enzymes in isolated chloroplasts, Polyphenoloxidase in Beta vulgaris. Plant Physiol. 1949;24(1):1.

77. Zhang Z, Pang X, Yang C, Ji Z, Jiang Y. Purification and structural analysis of anthocyanins from litchi pericarp. Food Chem. 2004;84(4):601-4.
78. Gong Y, Fang F, Zhang X, Liu B, Luo H, Li Z, Zhang X, Zhang Z, Pang X. B type and complex a/B type epicatechin trimers isolated from litchi pericarp aqueous extract show high antioxidant and anticancer activity. Int J Mol Sci. 2018;19(1):301.

79. Retamales HA, Scharaschkin T. A staining protocol for identifying secondary compounds in Myrtaceae. Appl Plant Sci. 2014;2(10):1400063.

80. Rzeppa S, Von Bargen C, Bittner K, Humpf HU. Analysis of flavan-3-ols and procyanidins in food samples by reversed phase high-performance liquid chromatography coupled to electrospray ionization tandem mass spectrometry (RP-HPLC-ESI-MS/MS). J Agr Food Chem. 2011;59(19):10594-603.

81. Pang X, Halaly T, Crane O, Keilin T, Keren-Keiserman A, Ogrodovitch A Galbraith D, Or E. Involvement of calcium signalling in dormancy release of grape buds. J Exp Bot. 2007:58(12):3249-62.

82. Wrolstad R, Culbertson J, Cornwell C, Mattick L. Detection of adulteration in blackberry juice concentrates and wines. J Assoc Off Anal Chem. 1982;65(6): 1417-23.

83. Chakraborty TK, Das N, Sengupta S, Mukherjee M. Accumulation of a natural substrate of laccase in gills of Pleurotus Florida during sporulation. Curr Microbiol. 2000;41(3):167-71.

84. Vaknin H, Bar-Akiva A, Ovadia R, Nissim-Levi A, Forer I, Weiss D, Oren-Shamir M. Active anthocyanin degradation in Brunfelsia calycina (yesterday-todaytomorrow) flowers. Planta. 2005;222(1):19-26.

85. Poustka F, Irani NG, Feller A, Lu Y, Pourcel L, Frame K, Grotewold E. A trafficking pathway for anthocyanins overlaps with the endoplasmic reticulum-to-vacuole protein-sorting route in arabidopsis and contributes to the formation of vacuolar inclusions. Plant Physiol. 2007;145(4):1323-35.

\section{Publisher's Note}

Springer Nature remains neutral with regard to jurisdictional claims in published maps and institutional affiliations.

Ready to submit your research? Choose BMC and benefit from:

- fast, convenient online submission

- thorough peer review by experienced researchers in your field

- rapid publication on acceptance

- support for research data, including large and complex data types

- gold Open Access which fosters wider collaboration and increased citations

- maximum visibility for your research: over $100 \mathrm{M}$ website views per year

At $\mathrm{BMC}$, research is always in progress.

Learn more biomedcentral.com/submission 